\title{
Cancer Tissue Classification, Associated Therapeutic Implications and PDT as an Alternative
}

\author{
TAMARISK K. HORNE and MARIANNE J. CRONJE
}

Biochemistry Department, University of Johannesburg, Johannesburg, South Africa

\begin{abstract}
Carcinogenesis occurs via mutation of critical genes conferring enhanced survival and protection to the ensuing tissue. Current therapies in use garner success due to their specificity for certain intracellular targets. This particularity, whist beneficial in identifying tumorigenic from normal tissue states, is limited by the variations in genol phenotypic profiles displayed between tumor tissue types. As such, tissue-specific therapeutic combinations and adjuvants are often required for adequate effect, but present symptomatic complications and occasionally generate secondary carcinogenesis displaying multi-drug resistance (MDR). An accumulation of research over the recent years has suggested that photodynamic therapy (PDT) with macrocycle photosensitizers are a promising alternative. Its administration method and toxicity mechanism present attractive features for potentially overcoming MDR cancers of multiple tissue origins with limited symptomatic onsets. Herein, we highlight these potentials as referenced against existing therapeutics and consider the impact of macrocyclePDT for broad spectrum application regardless of tumorigenic resistance profiles.
\end{abstract}

\section{Tissue Homeostasis and Cancer Development}

Homeostasis within the body is maintained through strict regulation of cellular lifespan. The decision of a cell to grow, divide, repair or die lies within the regulatory function of interacting pathways that govern the cell cycle, while a close

This article is freely accessible online.

Correspondence to: Marianne J. Cronje, Biochemistry Department, University of Johannesburg, APK Campus, Johannesburg, 2006, South Africa. Tel: +2711 559 2404, e-mail: mariannec@uj.ac.za

Key Words: Photodynamic therapy, macrocycles, multi-drug resistance, genetic variance, cancer tissue types, review. interaction between growing, quiescent and dying cells ensures overall cell turnover which is tightly regulated so that tissue mass is maintained at a near steady-state. In cancer, this balance between proliferation and suicide is disturbed. Cancer can therefore be described as the unrestricted tissue expansion due to uncontrolled cell growth (1). From a medical standpoint, this confers nutrient and oxygen depletion on the body resulting in overwhelming physical burden and death.

Biochemically, cells experience daily genetic lesions as a consequence of environmental exposure, normal 'wear and tear', errors during new DNA synthesis, and mitosis which are continuously identified at cell-cycle checkpoints and successfully repaired. Genetic mutations arise when these lesions are misrepaired during sequence patch-up or nucleotide excision. Known as point-mutations these include nucleotide deletions, -insertions, -duplications and rearrangements. Additionally, larger chromosomal alterations encompass amplifications of fragments resulting in multiple gene copies and translocations or rearrangements (gene relocation to another promoter leading to mis-regulated expression) which occur during cell division $(2,3)$. The position, amount and degree of mutations determine the cellular potential to bypass selection barriers and if so, are carried over to daughter clones. This incurs genetic instability at the nucleotide sequence and/or chromosome, leading to a gradual buildup of multiple mutations (mutational set) and an eventually altered genotype (4). Problems arise when these mutations confer cellular growth, differentiation and survival benefits $(4,5)$. Termed carcinogenesis, this is identified from other mutational sets by the two key classes of regulatory genes affected;

1. Proto-oncogenes: highly controlled expression of growth factors, their receptors, signal transducers, and transcription factors that collectively promote cell proliferation. Carcinogenesis is generated by over-activated forms (i.e. oncogenes) which flood critical regulatory pathways with a constitutive supply of proliferative signals. 
Oncogenes are particularly sensitive to changes in expression rate as their allele pairs exert genetic dominance, i.e. mutation of one confers enhanced expression of the pair $(1,5)$.

2. Tumor-suppressor genes (TSGs): code for inhibitory products preventing cell proliferation via cell cycle arrest for DNA repair or initiating cell suicide. During carcinogenesis, these are inhibited via inherited mutations of the original genes, epigenetic mechanisms of histone modification and DNA methylation or at the product level via protein interference. The allele pairs are recessive, thereby requiring both genes to be mutated before loss of function occurs $(1,5,6)$.

Through these genes, a tissue state converts from a mortal to an immortal (neoplastic) phenotype. This requires a monumental shift in the systemic nature of cellular processes and therefore extends far beyond the pathways directly associated with the mutated gene products. Multiple pathways are branched and interconnected in an intensely complicated way such that, changes in the rate of one confers differential influence over many resulting in marginally identical outcomes. Termed the "Hallmarks of Cancer", these phenotypic characteristics act as a guide in distinguishing carcinogenesis (extensively detailed in 1,6-11).

\section{Cancer Genotype/Phenotype Complexity and the route of Therapeutic Resistance}

Carcinogenesis produces a carcinoma and the generation of a tissue mass comprised of carcinogenic cells is termed tumorigenesis resulting in tumor. Whilst the "hallmarks" are defining end-point features of all static tumor masses, it is the subtle disparities between them which contribute to the complexity of their responses to therapeutics. Therefore, carcinomas can be categorized beyond these "hallmarks" due to histological origin and subsequent genotypic-derived behavioural characteristics $(8,9,11)$.

2.1. Classification by Histological Origin. Note that for the purposes of this review, the following classification encompasses static cancers only and omits those of the blood and lymph systems:

1) Squamous Cell Carcinoma ( $S C C / S q C C)$ : Squamous cells comprise epithelial tissue forming the main part of skin epidermis and internal lining of most cavities. As such SCC encompasses a wide range of tissues including; skin, oral and nasal cavity, digestive tract, lung, bladder, prostate and cervix. Despite their numerous sources, SCC exhibits histological distinctions of atypical shapes, disrupted cytoplasmic keratin/tonofibril characteristics, and tubular patterns. These cancers generally display low risk for metastasis and good survival prognoses (12-14).

2) Basal Cell Carcinoma (BCC): Carcinogenesis of epidermal cells other than squamous, $\mathrm{BCC}$ includes majority of skin cancers. Rarely metastatic but invasive to surrounding tissues it is classified based on its dermal location and required therapeutic approach into, superficial, infiltrative and nodular. These three groups are further classified into a wide range of subtypes depending on the body part location and pigmentation ratios (14-17).

3) Adenocarcinoma: Carcinogenesis of heterogeneous epithelial tissue which display exocrine and/or endocrine characteristics but are not necessarily of primary glandular function. Divided into adenoma (benign) and adenocarcinoma (malignant), glandular tissues of the latter are referred to as neuroendocrine tumors and include skin, breast, thyroid, pituitary, pancreas, gall bladder, prostate, ovaries and adrenal glands. Tissues exhibiting glandular traits include lung, oesophagus, liver, kidney, middle and lower digestive tract and uterus, amongst others. The heterogeneous source of adenocarcinomas imparts very few general characteristics for discrimination and may be differentiated to closely resemble their tissue type or not. However, all display aggressive, acute onsets with highly metastatic tendencies resulting in therapeutic complications and poor prognoses (18-21).

2.2. Hetero-cellular Populations. Histological complexity of cancer is further compounded by hetero-cellular compositions and tissue-genotype susceptibilities $(8,11)$. Externally influenced by the microenvironment of neighboring tissues, tumors are characterized as highly complex "organs" consisting of more than one carcinogenic population. Presence of additional differentiated cell types, each contributing to sustained survival of the tumor mass include cancer stem cells, endothelial cells, specialized mesenchymal cells (pericytes), mesenchymal stem and progenitor cells, immune inflammatory cells, and cancer associated fibroblasts. Understanding its phenotypic nature therefore also requires identifying the influences these impart on the tumorigenic system $(6,8,9,11)$.

2.3. Tissue-specific Genotypic Variations. Tissue types, e.g. lung etc. are all distinguished by unique geno- and phenotypic profiles for cellular function driven by the particular role that tissue needs to fulfill for the larger body system (22). The random combinations of multiple key mutations has been reported to generate a plethora of distinctive cancer genotypes per tissue type with little degree of prediction (4, $5)$. Therefore, whilst holistically mediated by universal mutations to trademark critical genes, carcinogenesis also demonstrates additional tissue-specific geno- and phenotypic variations that together culminate in the same classic hallmarks observed $(22,23)$. Over the years, medical advances have identified over 100 distinct cancer tissue types and subtypes for both static tumor masses and monocytic mobile populations (e.g. leukemia and lymphoma). Different 
Table I. Tissue-specific deficiencies and surfeits in four cancer genotypic/phenotypic profiles. These highlight some genetic defects/augmentations commonly associated with a particular cancer tissue type.

\begin{tabular}{|c|c|c|c|c|c|c|c|}
\hline $\begin{array}{l}\text { Genotype } \\
\text { deficiencies }\end{array}$ & $\begin{array}{l}\text { Phenotype } \\
\text { deficiencies }\end{array}$ & $\begin{array}{l}\text { Consequence on } \\
\text { survival/cell death }\end{array}$ & Ref. & $\begin{array}{l}\text { Genotype } \\
\text { Surfeits }\end{array}$ & $\begin{array}{l}\text { Phenotype } \\
\text { Surfeits }\end{array}$ & $\begin{array}{c}\text { Consequence on } \\
\text { survival/cell death }\end{array}$ & Ref \\
\hline \multicolumn{8}{|c|}{ Breast: } \\
\hline$B R C A 1$ mutation & $\begin{array}{l}\text { Loss of tumor- } \\
\text { suppressor } \\
\text { protein BRCA1 }\end{array}$ & $\begin{array}{l}\text { Un-regulated cell } \\
\text { growth, impaired } \\
\text { DNA repair }\end{array}$ & 176 & $\begin{array}{l}\text { AURKA Aurora } \\
\text { polymorphism } \\
91 \mathrm{~T} \rightarrow \mathrm{A}\end{array}$ & $\begin{array}{c}\text { A kinase } \\
\text { dysregulation and } \\
\text { overexpression }\end{array}$ & $\begin{array}{c}\text { Enhanced cell survival, } \\
\text { metastasis and } \\
\text { apoptosis inhibition }\end{array}$ & 177 \\
\hline$B R C A 2$ mutation & $\begin{array}{l}\text { Impaired function } \\
\text { of tumor-suppressor } \\
\text { protein BRCA2 }\end{array}$ & $\begin{array}{l}\text { Reduced genomic } \\
\text { stability via loss of } \\
\text { gene mutation repair }\end{array}$ & 177 & $\begin{array}{c}H E R 2 \\
\text { amplification }\end{array}$ & $\begin{array}{l}\text { HER2 and HER3 } \\
\text { GFR } \\
\text { overexpression }\end{array}$ & $\begin{array}{l}\text { Activate survival/ } \\
\text { proliferation gene } \\
\text { transcription }\end{array}$ & 188 \\
\hline CASP3 mutation & $\begin{array}{l}\text { Loss of Caspase-3 } \\
\text { enzyme }\end{array}$ & $\begin{array}{l}\text { Impaired execution } \\
\text { of apoptosis }\end{array}$ & 178 & ESR1 mutation & $\begin{array}{c}\text { Overexpression } \\
\text { of ER } \\
\text { (oestrogen receptor) }\end{array}$ & $\begin{array}{c}\text { Stimulated } \\
\text { proliferation and } \\
\text { DNA replication }\end{array}$ & 188 \\
\hline \multicolumn{8}{|c|}{ Skin (Melanoma): } \\
\hline Apaf- 1 mutation & $\begin{array}{l}\text { Loss of Apaf-1 } \\
\text { protein for } \\
\text { apoptosome } \\
\text { formation }\end{array}$ & $\begin{array}{l}\text { Impaired mediation } \\
\text { of p53-dependant } \\
\text { apoptosis }\end{array}$ & 179 & $\begin{array}{l}B R A F \text { mutation } \\
\quad(\mathrm{V} 600)\end{array}$ & $\begin{array}{c}\text { ERK } \\
\text { hyperactivation }\end{array}$ & $\begin{array}{l}\text { Hyperproliferation } \\
\text { and enhanced } \\
\text { survival }\end{array}$ & 103 \\
\hline $\begin{array}{l}\text { PPP6C mutation } \\
\text { (R264C) }\end{array}$ & $\begin{array}{c}\text { Dysfunctional PP6 } \\
\text { protein component } \\
\text { of phosphatase } \\
\text { complex }\end{array}$ & $\begin{array}{l}\text { Increased cell cycle } \\
\text { and mitotic rates }\end{array}$ & 180 & $\begin{array}{c}M D M 2 \\
\text { up-regulation }\end{array}$ & $\begin{array}{l}\text { Increased inactivation } \\
\text { of p53 by } \\
\text { E3 Ligase murine } \\
\text { double minute- } 2\end{array}$ & $\begin{array}{l}\text { Silenced p53 } \\
\text { induced } \\
\text { senescence } \\
\text { and cell death }\end{array}$ & 189 \\
\hline $\begin{array}{l}\text { Fas (CD95) } \\
\text { down-regulation }\end{array}$ & $\begin{array}{l}\text { Loss of Fas surface } \\
\text { receptor expression }\end{array}$ & $\begin{array}{l}\text { Impaired receptor- } \\
\text { mediated apoptosis } \\
\text { for pro-survival }\end{array}$ & 181 & $\begin{array}{l}\text { TERT promoter } \\
\text { mutation }\end{array}$ & $\begin{array}{c}\text { High telomerase } \\
\text { levels }\end{array}$ & $\begin{array}{l}\text { Increased cell } \\
\text { lifespan }\end{array}$ & 190 \\
\hline \multicolumn{8}{|c|}{ Lung: } \\
\hline TIMP3 silencing & $\begin{array}{l}\text { Reduced, metallo- } \\
\text { proteinase } \\
\text { inhibitor } 3 \text { function }\end{array}$ & $\begin{array}{c}\text { Enhanced } \\
\text { angiogenesis } \\
\text { and metastasis }\end{array}$ & 182 & KRAS mutation & $\begin{array}{l}\text { KRAS protein } \\
\text { activation }\end{array}$ & $\begin{array}{c}\text { Increased signal } \\
\text { transduction and } \\
\text { drug resistance }\end{array}$ & 191 \\
\hline HOXAI & $\begin{array}{l}\text { Low Homeobox } \\
\text { protein Hox-A1 } \\
\text { expression/activity }\end{array}$ & $\begin{array}{c}\text { Inhibited cell } \\
\text { cycle arrest } \\
\text { and apoptosis, } \\
\text { enhanced } \\
\text { chemoresistance }\end{array}$ & 183 & $\begin{array}{c}\text { TOP } 2 A \\
\text { overexpression }\end{array}$ & $\begin{array}{c}\text { Abundant } \\
\text { Topoisomerase II } \alpha\end{array}$ & $\begin{array}{c}\text { Facilitates } \\
\text { transcriptional } \\
\text { processes for mitosis }\end{array}$ & 19 \\
\hline $\begin{array}{l}\text { hRAB37 } \\
\text { down-regulation }\end{array}$ & $\begin{array}{c}\text { Low Rab37 } \\
\text { protein expression }\end{array}$ & $\begin{array}{l}\text { Enhanced } \\
\text { metastasis }\end{array}$ & 184 & $\begin{array}{l}D D R 2 \text { mutation } \\
\quad(\mathrm{S} 768 \mathrm{R})\end{array}$ & $\begin{array}{l}\text { Discoidin domain } \\
\text { receptor tyrosine } \\
\text { kinase } 2 \text { up-regulation }\end{array}$ & $\begin{array}{l}\text { Enhanced growth, } \\
\text { differentiation and } \\
\text { metabolism in SCC }\end{array}$ & 192 \\
\hline \multicolumn{8}{|c|}{ Oesophagus: } \\
\hline $\begin{array}{l}E C R G 4 \\
\text { down-regulation }\end{array}$ & $\begin{array}{l}\text { Low ECRG4 } \\
\text { tumor-suppressor } \\
\text { protein levels }\end{array}$ & $\begin{array}{c}\text { Enhanced lymph } \\
\text { node metastasis } \\
\text { Enhanced drug }\end{array}$ & 185 & $\begin{array}{c}\text { AURKA } \\
\text { polymorphism }\end{array}$ & $\begin{array}{l}\text { Aurora A kinase } \\
\text { dysregulation } \\
\text { and overexpression }\end{array}$ & $\begin{array}{c}\text { Enhanced cell } \\
\text { survival, growth } \\
\text { signal, proliferation }\end{array}$ & 177 \\
\hline $\begin{array}{l}G P X \\
\text { down-regulation }\end{array}$ & $\begin{array}{l}\text { Low GPX levels } \\
\text { for detoxification }\end{array}$ & $\begin{array}{c}\text { resistance and } \\
\text { cell signaling }\end{array}$ & 186 & $91 \mathrm{~T} \rightarrow \mathrm{A}$ & & $\begin{array}{l}\text { and metastasis, } \\
\text { apoptosis inhibition }\end{array}$ & \\
\hline $\begin{array}{l}\text { DIRAS1 } \\
\text { down-regulation }\end{array}$ & $\begin{array}{l}\text { Reduced receptor } \\
\text { signal transduction }\end{array}$ & $\begin{array}{l}\text { Increased cell } \\
\text { proliferation } \\
\text { and metastasis }\end{array}$ & 187 & XPO1 mutation & $\begin{array}{l}\text { Overexpressed } \\
\text { Exportin } 1\end{array}$ & $\begin{array}{l}\text { Facilitates kinase } \\
\text { enzyme transport } \\
\text { for cell proliferation }\end{array}$ & 193 \\
\hline
\end{tabular}

tissues harboring the same carcinoma type incur variations in their characteristics for behavior and treatment sensitivity. Likewise, so do identical tissue types between different individuals $(5,8)$. The supplementary literature in Table I examples these aspects via a compilation of extensively simplified data between four highly studied cancer tissuetypes and aims to merely highlight some of the characteristics responsible for their varying natures. Whilst the features and genes compiled in Table I are far from the only ones exhibited by these tissues, their involvement has 
become synonymous with particular tissue types over others. It is the varying combinations of these and other regulated genes displayed within each tissue type that hallmarks its genetic profile, subsequent phenotypic nature and therapeutic response.

\section{Implications for Current Therapeutics}

This high degree of mutational variation has led to the development of multiple therapeutic approaches for targeting tissue-specific abnormalities. Critical understanding of differential characteristics between cancer tissue types and subtypes has classed therapies into those that; 1) target growth or proliferation aspects via inhibitory and immune-sensitizing agents versus those that, 2) attempt to overcome death resistance via cell damage and death induction $(4,5,8)$.

Table II highlights key aspects and applications of currently established systemic cancer therapeutics applied individually, in tandem or as adjuvants to each other. The most commonly used therapeutic branch; Chemotherapy, encompasses an extensive assortment of toxic chemical compounds for oral, intravenous (bloodstream and lymph), intrathecal (spinal column) or regional (organs or abdominal cavity) cancer treatments (24-26). The extent depends on cancer type as drugs exert a particular effect on specific intracellular targets and are therefore categorized according to their mechanism of effect. Development has yielded two alternative chemotherapies namely; "Biological Therapy" (9, $27)$ and "Immune Therapy" (28, 29). These apply the intricacy and availability of cellular molecules/systems to generate blockades against cancer development and/or initiate defensive responses to its presence.

Radiotherapy (a.k.a. radiation therapy) employs lethal doses of ionizing radiation to the tumor mass, ideally when cells are in the mitotic phase. This damages DNA for cell retardation and death $(27,30)$. Internal administration utilizes radioisotope therapy and combinations with immuno-agents for targeted Radioimmunotherapy (26, 31-35). Gene therapy aims to restore normal gene function in order to regain growth control or terminate existence. Specific targeting with viral- and non-viral delivery vectors (e.g. surface-coated microspheres) transport genetic variants for genome manipulation enabling direct or indirect therapies depending on the cell function being targeted (11, 27, 36-38).

Whilst prognoses have improved throughout these regimens under study, two critical issues have surfaced regarding cancers of genetic variance:

3.1. Systemic therapies exhibit low tissue specificity. Many chemotherapies, in addition to poor concentration yields generating weak target responses, also exhibit low exclusivity to tumor tissue/cells. This broad specificity to tissues mimicking cancer characteristics (e.g. high proliferative rates of blood, bone, mouth, intestinal tract, nose, nails, hair and sexual organs), or tissues responsible for xenobiotic clearance (e.g. liver and kidney) inadvertently suffer undirected damage upon administration (23). Loss of cell function results in cell renewal shutdown for tissue maintenance, immunosuppression incurring secondary infections, impairment of organ system communications and organ damage, myelosuppression anemia and acute myeloid leukemia $(39,40-45)$. Similarly, radiotherapies also impart toxicity on normal tissues generating Acute- (epithelial damage, nausea, diarrhea and oedema), and Late- (fibrosis, alopecia, lymphedema, cognitive decline and heart disease) responses $(30,31,46-51)$ as well as an increased risk for secondary cancer development (52). Alternatively, gene therapy limitations occur via low specific tumor cell/gene targeting, low transfection efficiency, uncontrolled surrounding tissue damage via toxic product leakage and, onset of flu like symptoms. Additionally, preventing permanent incorporation of genetic changes and other ethical factors are problematic $(1,38,53)$.

This combination of being too specific within the cellular system and not specific enough within the organ-tissue system has led to a conundrum of complications. Approaching this from a negative angle one could argue that complete eradication with no recurrence is more a challenge of lucky chance with regards to compatibilities between tissue type, therapeutic application, genetic profile, low heterogeneity, high tissue target-therapeutic agent interaction and a "goldilocks" scenario of therapeutic dosage that is "just right" so as to impart no disabling side effects.

3.2. Therapeutic agents target a single abnormality or family of similar abnormalities. Whilst it is beneficial to design therapies targeting particular abnormalities critical for cell function or who impart influence multiple pathway systems, this approach may, in some cases, be flawed due to:

- Insufficient damage inflicted on one target to overcome survival mechanisms and induce adequate death responses. The intricately interconnected pathway systems displayed by cells is a double edged sword. Many components exhibit multiple functions or interactions across a number of pathway systems whose therapeutic disruption or stimulation could yield broad scale collapse or activation of critical mechanisms for a desired outcome. Conversely, this multifunctionality, many of which are yet to be elucidated, could interfere via protection $(26,54,55)$, active damage repair $(56,57)$ or compensation $(58,59)$ thereby rendering the treatment largely ineffective. This has prompted the use of drug cocktails and modified chemotherapeutics (e.g. chemoradiotherapy, chemo-radioimmunotherapy) to encompass several targets for crippling of overall cell 
Table II. Compilation of current targeted systemic therapies for cancer treatment.

\begin{tabular}{|c|c|c|}
\hline Therapy & Target & Ref. \\
\hline \multicolumn{3}{|l|}{ Chemotherapy: } \\
\hline Alkylating Agents & $\begin{array}{l}\text { Alkylate proteins and nucleic acids independent of the cell-cycle phase } \\
\text { for DNA accessibility, e.g. cisplatin, carboplatin, oxaliplatin. }\end{array}$ & 194,195 \\
\hline Anti-metabolites & $\begin{array}{l}\text { Broad class of molecular analogues that disrupt proliferation and induce cell death via genomic } \\
\text { enzyme competitive-binding or direct nucleotide strand incorporation, e.g. fluorouracil and pentostatin. }\end{array}$ & 194,196 \\
\hline Cytoskeletal agents & $\begin{array}{l}\text { Natural and semi-synthetic drugs that induce cytoskeletal microtubule dysfunction preventing } \\
\text { completion of mitosis, e.g. paclitaxel, docetaxel and vinblastine. }\end{array}$ & $\begin{array}{c}194,197 \\
198\end{array}$ \\
\hline Topo-isomerase inhibitors & $\begin{array}{l}\text { Inhibit critical activity of topoisomerase I and II enzymes required for genomic transcription and } \\
\text { replication potentials, e.g. topotecan and etoposide. }\end{array}$ & 195,199 \\
\hline Cytotoxic antibiotics & $\begin{array}{l}\text { Broad group of compounds collectively exert toxic effects on individual cell function components } \\
\text { including DNA intercalation, ROS production, metabolic pathway inhibitors and free-energy carriers, } \\
\text { e.g. actinomycin, doxorubicin and mitomycin. }\end{array}$ & $\begin{array}{c}200,201 \\
202\end{array}$ \\
\hline Hormone/endocrine agents & $\begin{array}{l}\text { A special branch of chemotherapy aiming to impede hormone dependent cancer types by negating } \\
\text { stimulatory effects of hormones such as oestrogen and progesterone. Limitations involve the } \\
\text { selective targeting of those cancers reliant on hormonal stimulation and the development of } \\
\text { secondary endometrial and uterus cancers from its use. }\end{array}$ & $\begin{array}{c}203,204 \\
205\end{array}$ \\
\hline \multicolumn{3}{|l|}{ Biological/Immune Therapy: } \\
\hline Boosting & $\begin{array}{l}\text { Cell-based Vaccination with multiple surface tumor-associated antigens or cancer cell homogenates } \\
\text { to increase cytotoxic T-Lymphocyte response efficiency. This involves removing, amplifying and } \\
\text { returning a variety of immune cells activated against a particular cancer to augment the immune response. }\end{array}$ & $\begin{array}{c}206,207 \\
28\end{array}$ \\
\hline Restoring & $\begin{array}{l}\text { Interferons, interleukins, and other cytokines administered to imitate or influence the natural immune } \\
\text { response i.e. Cytokine Therapy. }\end{array}$ & 208,209 \\
\hline Directing & $\begin{array}{l}\text { Monoclonal antibodies (mAb) synthesized against cell surface proteins typical of cancer. Two types } \\
\text { of mAb are applied; naked and conjugated. These sensitize the immune system via antibody-dependent } \\
\text { cell-mediated cytotoxicity (ADCC), complement-dependent cytotoxicity inducing membrane protein } \\
\text { pore damage, or antagonistic mAb binding of cancer stimulatory receptors for signaling inhibition. } \\
\text { Conversely, mAb-drug conjugates with both chemo-drugs and radioisotopes have incurred multiple } \\
\text { drawbacks in practical use. }\end{array}$ & $\begin{array}{l}210,211 \\
212,213\end{array}$ \\
\hline \multicolumn{3}{|l|}{ Radiotherapy: } \\
\hline Radioisotope Therapy (RIT) & $\begin{array}{l}\text { Involves systemic/oral administration of ion radioisotopes for cancer uptake and damage. } \\
\text { These include }{ }^{177} \mathrm{Lu},{ }^{131} \mathrm{I},{ }^{213} \mathrm{Bi},{ }^{210} \mathrm{Po} \text {, and }{ }^{90} \mathrm{Y} \text {. For additional targeting, these can be encapsulated } \\
\text { in microspheres or conjugated to antibodies and other immuno-agents (Radioimmunotherapy). } \\
\text { The latter sports additional sensitization of the immune system to cancer sites. }\end{array}$ & $\begin{array}{c}31,33 \\
34\end{array}$ \\
\hline \multicolumn{3}{|l|}{ Gene-Directed Therapy: } \\
\hline Direct & $\begin{array}{l}\text { 1) Reintroduce silenced TSGs, e.g. P53 gene enabling apoptosis. } \\
\text { 2) Introduce siRNA/microRNA to block malignant oncogene expression e.g. } \\
\text { inhibiting overexpression of Bcl-2. }\end{array}$ & 27,214 \\
\hline Indirect & $\begin{array}{l}\text { 1) Reintroduction of immunogenic cytokine genes increasing tumor susceptibility to external } \\
\text { defense responses e.g. MAGE gene. } \\
\text { 2) Introduction of genes encoding enzymes to convert non-toxic substrates into toxic products } \\
\text { e.g. Herpes Simplex Virus Tyrosinase Kinase. }\end{array}$ & 37 \\
\hline
\end{tabular}

functions $(5,22,25,31,60-64)$. Treatment success is significantly improved but carries a variety of unfavorable consequences and acute life-threatening toxic effects to the body $(22,65)$.

- Target abnormality might not be present in the carcinoma type or, only be present in specific subpopulations due to tumor heterogeneity.
The diverse genetic variations impart a unique cocktail of resistance traits which complicate design and implementation of successful cancer therapies $(8,23)$ and exhibition of pretherapeutic resistance hallmarks "innate- or intrinsicresistance" $(22,66)$. Melanomas, breast-, prostate-, colon-, and lung cancers express strong variations of this to chemoand radio-therapeutics ensuing high failure rates $(8,22,67)$. Occasionally, increasing drug dosage overcomes this. 
However, this regularly confers increased general toxicity without enhanced efficacy due to the lack of sufficient targets available (26). Recent research has attributed resistance and recurrence to tumor mass heterogeneity. Mesenchymal stromal cells, tumor initiating cells, innate inflammatory immune cells and myofibroblast interactions exert external therapeutic negations via signals for protection and survival (extracellular matrix proteins), epigenetics, oncologic trogocytosis and cancer stem cell conversion. Consequently, therapies may only impart a partial eradication of the tumor $(23,68-72)$. Similarly, antibody targeting of immunotherapies have fallen short, exhibiting traits of inconsistent surface-antigen expression, limited antibody distribution and tissue penetration due to molecular size through tumor vasculature, low surface-antigen binding incurring weak internalization and superficial cytotoxicity, and the presence of multiple antigens demonstrating competition for immune responses $(14,23,73)$.

- Particular target could incur a quickening of disease development or metastatic potential for escape.

Many therapeutics inadvertently generate more aggressive tumor phenotypes. Stimulation of key proteins forces an Epithelial-to-mesenchymal transition (EMT). During this, cells transform from polarized epithelial- to highly mobile mesenchymal phenotypes thereby enhancing metastatic potential (74). This has also been associated with therapeutic stimulation of the tumor microenvironment $(70,75-77)$.

- Therapy is limited to specific cancers.

Aspects of tumor heterogeneity, genetic profiles and drug susceptibility enable pairing with certain drug combinations for maximal effect. This however, limits the potential broad applications of available therapies to specific cancer types. Identical treatment regimens are regularly less effective against other cancer tissue types and in some cases, the same tissue type via mutational variation $(22,65)$. This is most prominently observed in biological- and immune-therapies which are highly cancer-type specific. Here, particular therapies are administered according to the marker profile that identifies possible areas of treatment susceptibility ( 9 , 27) and success requires extensive knowledge of the cancer attributes, mechanisms of resistance and the communication between immune system and tumor cells (78). Furthermore, treatment scenarios may result in eradication of one tumor population but enhanced tumorigenesis of another (23). This has been observed with various radiotherapy administrations where success relies heavily on cancer cell genetic sensitivity and low hypoxic conditions. This non-uniform cellular targeting results in under-targeted subpopulations surviving the initial onslaught $(30,31,48)$. Genotype and phenotype identification is, therefore, required to select a therapy or combination of therapies with the highest potential success.
- Attack on a particular target may induce signaling effects that confer resistance to surviving cells.

Cancer cells surviving the initial treatment commonly develop resistance by altering their genetic profiles to overcome the target susceptible to the therapy $(22,66)$. This results in frequent chemoresistance despite its vast application repertoire as summarized in Table I $(5,22,53$, $55,79,80)$. Additionally, these can yield reduced drug affinities or uptake resulting in cancer relapse and tumor recurrence with resistant phenotypes $(76,81)$, and secondary cancer developments $(82,83)$. The nature and mechanistics behind this phenotype is described in greater detail further on.

In truth, therapeutics have shown remarkable improvements in prognoses, indicating targets selected are critical for cell collapse (84). Efforts in these areas are by no means futile and the limitations thereof are fundamentally due to gaps in the current knowledge and methods for successful application. Whilst these imperfections are being addressed, progress is slow and remains a tedious task of perfecting a specific therapeutic approach for a particular carcinoma of unique genetic profile. Therefore, the need to establish a diversified therapy for broad spectrum application is a much desired alternative.

\section{Photodynamic Therapy}

Being a treatment modality, Photodynamic therapy (PDT) could potentially fulfill this role. As a unique branch of phototherapy, PDT has become a much researched field with its success driven by the distinctive combination of semitargeted administration and non-specific damage induction $(85,86)$.

Essentially, PDT comprises a minimally-invasive, threecomponent therapy involving the initial topical or systemic administration of a photosynthetic drug (Photosensitizer; Ps) which localizes within target tissue over time (87). Guided irradiation of the area with a high-energy, monochromatic light source of accordant wavelength (usually red/nearinfrared) results in photon-based Ps excitation. Upon dissipation, energy transfer generates highly Reactive oxygen species (ROS) resulting in broad scale irreversible photooxidative damage that ideally induces cell death $(88,89,90)$. On the molecular level, this process comprises complicated energetic interactions between the Ps electron system, cellular oxygen $\left(\mathrm{O}_{2}\right)$, light, potential ROS generating organic or inorganic molecules and target cellular components, the details of which are extensively described elsewhere $(88,90$, 91). Of note here, is the emphasis placed on subsequent ROS-generated damage for therapeutic administration.

4.1. ROS-Generated Non-specific Cellular Damage. The critical homeostasis of biomolecule concentrations for 
Table III. Listings of A) Macrocycle Ps attributes supporting their use in PDT applications, and B) PDT attributes endorsing its therapeutic application against cancer tissue variants and MDR.

A. Macrocycle Ps Attributes:

- Many natural and synthetic analogues mimic structures of natural biological chromophores enabling lowered

215,216

xenobiotic clearance or immune system triggering during administration. This increases circulation lifetimes.

- Commonly incurs widespread intracellular localization, particularly within critical organelles i.e. mitochondria,

88,137 endosomes, lysosomes and within the greater cytoplasmic area. This results in extensive photo-oxidative damage to the overall cell body.

- Manipulation of the condensation synthesis methods using different heterocyclic units and stable bridging atoms i.e.

217,218

219,220

221,222, nitrogen, oxygen, sulphur and carbon enable ring structure variations. This produces a wide range of derivatives tailored for a specific intended use.

- Unique nature of the ring structure enables core complexing with various metal ions for enhancement of their photophysical and environmental interaction properties. This increases excitation lifetimes and biological solubility respectively.

- Ligation with specific peripheral substituents enable enhancement of physiochemical and photophysical traits, which may be used to expand macrocycle use in PDT.

- Enhancement with peripheral ligands manipulates macrocycle uptake and localization to different parts of the cell. It is possible to target susceptible areas within a cell for maximal PDT effect.

- Alternatively, these enhancements can be used to administer a combination treatment of multiple Ps types for broad intracellular localization that collectively excite at a similar wavelength of light (known as Sandwich PDT). of excitation light sources to be used depending on the PDT application available and tissue penetration required.

B. Photodynamic Therapy Attributes:

- Boasts a high degree of application control, via targeted Ps delivery and manual application of stimulatory irradiation thereby minimizing damage to healthy tissue.

- Individually, neither Ps nor light components administered are toxic thereby imparting no adverse side effects commonly associated with other therapies.

- Utilizes a non-specific mechanism of oxidative cell damage. Any biomolecule in the vicinity is targeted and multiple targets can impart a "shotgun" effect to cell function such that recovery is more difficult.

Is less invasive than surgery allowing fast, simple application.

- A low risk profile of minimal side effects and tissue resistance allows for same-site repetitive applications in short time periods. This enables both elderly and people too sick for surgery to benefit from the treatment.

- The use of fiber optics and a broad wavelength range allows for both interstitial and endoscopic application covering a wide tissue application range.

No interference or cross-resistance with other therapeutics allows for adjuvant applications.

Low nuclear localization of Ps results in low risk of additional radical-generated DNA mutations following treatment. Immune sensitization. Surgery, chemo- and radiotherapies are immunosuppressive whereas ROS produced by PDT induces vascular damage leading to thrombosis, hemorrhage and inflammation. This alerts anti-tumor immunity thereby sensitizing the immune system for additive attacks on the tumor microenvironment of surviving cells.

- On a molecular level, PDT is known to induce multiple cell death cascades simultaneously or concomitantly via critical multi-functional components or "molecular switches". This implies that cells sufficiently damaged by PDT die via re-orientation of death cascade mechanisms when another is compromised by genotypic/phenotypic resistance profiles.

healthy cell function include ROS as signaling mediators of multiple cellular pathways that regulate survival, proliferation and cell death (92, 93, 94). However, excessive levels damage various cellular components including protein structure and activity (95), membrane integrity and dysfunction of trans-membrane protein channels (96), and nucleic acid lesions, base modifications and protein-DNA cross linking $(8,95,97)$. This broad scale damage is responsible for numerous diseases including carcinogenesis $(93,98,99)$. ROS levels are, therefore, tightly regulated (i.e. Redox State) via antioxidant defense mechanisms; free radical scavenger molecules and endogenous antioxidant enzymes $(94,100,101)$. In cancer, ROS levels are increased and antioxidant enzyme activities decreased conferring an advantage for proliferation, survival and chemoresistance $(8,98,99,102-106)$. Due to this constitutive oxidative stress, cancer displays increased sensitivities to ROS producing processes such as PDT as these could either increase ROS levels beyond a threshold point for damage-inducing death or stimulate antioxidant enzyme production thereby stunting growth and proliferation (107-109). 
Table IV. Summary of current macrocycle classes under popular research. Differential structure and photophysical traits of interest are also highlighted.

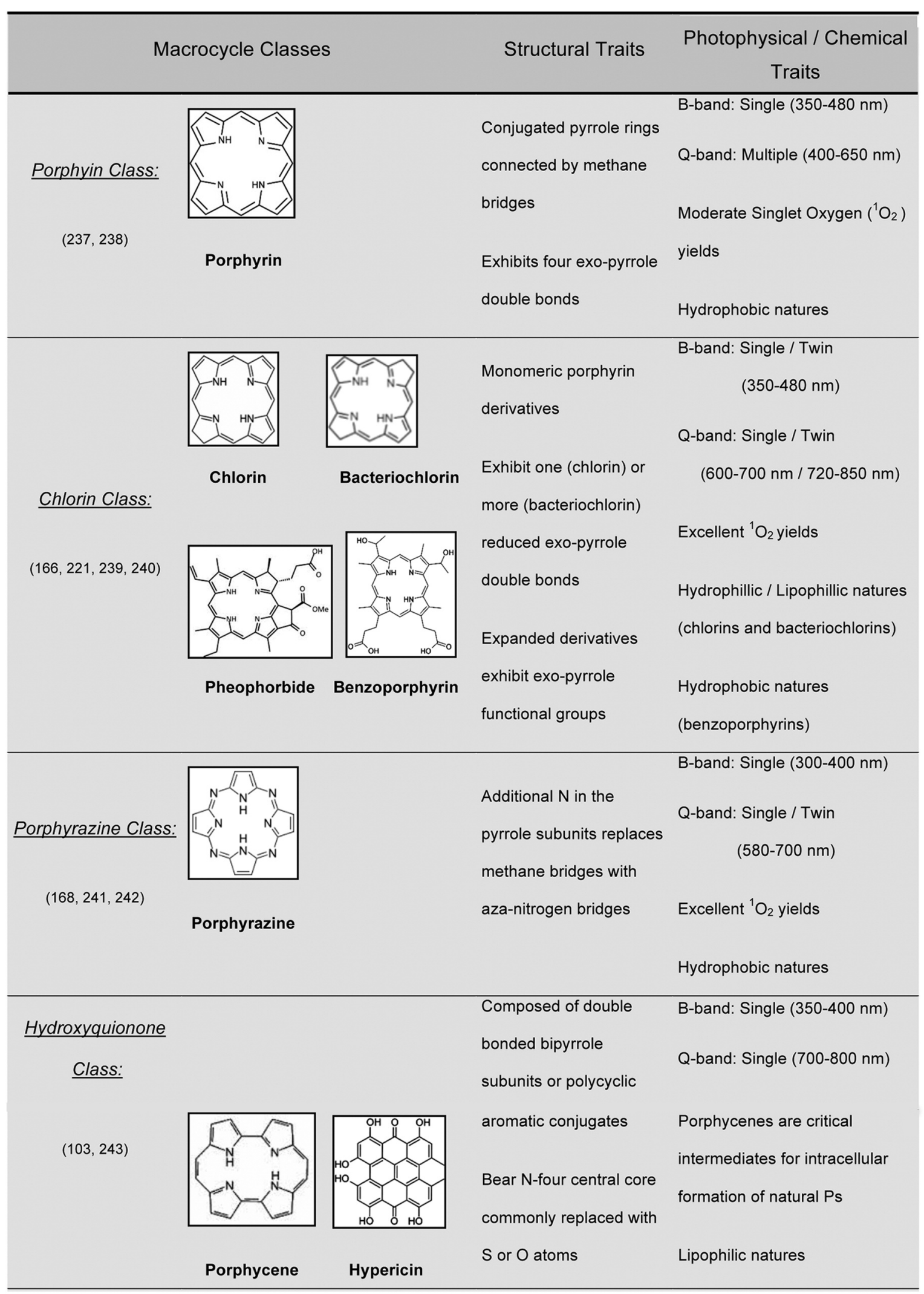


Table IV. Continued

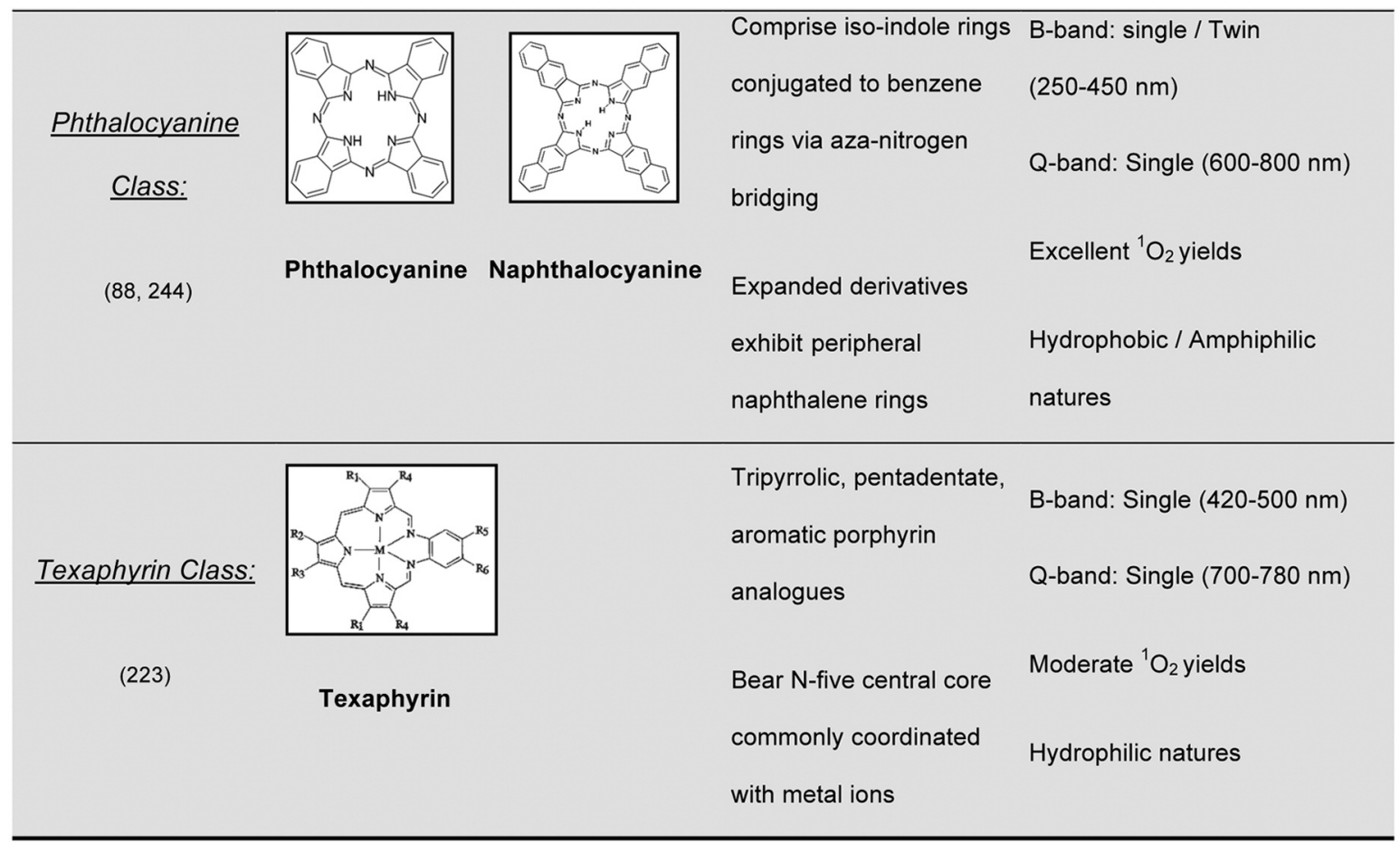

4.2. Macrocycle Ps for use in PDT. Whilst there is a vast range of Ps classes to choose from, each showcasing varying abilities for light energy absorption and transfer, one class - Macrocycles - has stood out. Of natural or synthetic origin, these Ps typically harbor a core ring design exhibiting an array of molecular structural varieties. This imparts unique physiochemical and photophysical profiles highlighting potential applications in specific medical niches such as PDT (110). Indeed, PDT only became a fully recognizable therapeutic to pursue following the use of porphyrin macrocycles by Dr. Thomas Dougherty in the $1970-80$ s $(85,86)$. Since then, a wide range of secondgeneration derivatives have been obtained from natural sources or alternatively synthesized. These boast many attractive advantages for PDT application based upon their synthesis methodology and subsequent ring structure attributes (Table IIIA).

Understanding the variations between their photophysical and physiochemical traits is critical, as the nature of these confer the potential of a particular macrocycle Ps for PDT application. Whilst there is currently a plethora of macrocycle classes and subclasses, each categorized largely by their physical structure and to a lesser extent, stable peripheral functional groups, there exist a popularity for certain classes over others. Summarized briefly in Table IV, these classes are among the most studied and highly successful regarding PDT today. Their success is attributed to the generalization that they bear many of the advantages described in Table IIIA.

\section{The Case in support of PDT Mechanism for Cancer Treatment}

PDT has gained much attention for its expanded application for cancer. Mechanistically, PDT boasts a number of attractive qualities over traditional cancer therapeutics and these are listed in Table IIIB. Furthermore, these qualities have endorsed its potential use against two cancer scenarios heavily limited to other applications, 1) A single Ps to be applied on multiple cancer tissue types, and 2) PDT could overcome MDR since the use of non-ionizing radiation and multi-targeting oxygen radicals sensitizes cells unresponsive to chemotherapeutics and radiotherapy.

5.1. Treatment of Multiple Cancer Tissue Types/Genetic Variants. PDT has been shown to be an effective anticancer treatment for a range of tissue types. The most common use involves treatment of non-melanoma cancers, cutaneous lymphomas and various non-cancerous skin conditions (111). Additionally, in vitro PDT with a single Ps has displayed significant broad spectrum application on differing carcinoma cell lines. Either in a single study or across many 
Table V. Summary of four extensively reported macrocycle Ps (Hypericin, 5-aminolevulinic acid, metallo-phthalocyanine and pheophorbide a) within in vitro studies against cancer. Listing includes the various tissue types investigated and the critical findings reported in each case.

\begin{tabular}{lcc}
\hline Macrocycle Ps: & \multicolumn{2}{c}{ Reported Studies: } \\
\cline { 2 - 3 } Description: & Ref.: & Tissue Types: \\
\hline $\begin{array}{l}\text { Hypericin (Hyp): } \\
\text { Phenanthroperylene } \\
\text { quinone of natural } \\
\text { origin from the } \\
\text { plant St. John's }\end{array}$ & 245 & $\begin{array}{c}\text { Glioblastoma brain } \\
\text { (U373 MG, LN229, T98G) }\end{array}$ \\
$\begin{array}{l}\text { wort (Hypericum } \\
\text { perforatum). } \\
\text { (245) }\end{array}$ & 246 & $\begin{array}{c}\text { Oesophageal: SCC } \\
\text { (Kyse-140) Adenocarcinoma } \\
\text { (OE-33) }\end{array}$ \\
& 248 & $\begin{array}{c}\text { Cervical (HeLa) } \\
\text { Breast (MCF-7) } \\
\text { Lung (A549) }\end{array}$ \\
Ovarian (NuTu-19)
\end{tabular}

5-aminolevulinic acid (ALA):

ALA and its derivatives are harmless prodrugs in the heme synthesis pathway that produces protoporphyrin IX (PpIX). Excitation of PpIX induces the resulting phototoxicity. Addition of ALA boosts subsequent PpIX production thereby enhancing the PDT effect. $(162,215)$
Oesophageal SCC (Eca-109)

Colon (HCT116)

Liver (HepG2)

Leukemia (HL60)

Breast (MCF-7, T47D)

Bladder (HT1197)

Rat Carcinoma (WRC) Urothelial (RT4) Colon (HT29)

Glioblastoma brain (U87, U373)

Prostate (PC-3, DU145), Murine prostate

(TRAMP-C1, -C2)

PDT-derived variants of: Lung (CL1-5) Melanoma (A375) Breast (MDA-MB-231) Gastric: (KKLS, NKPS, TMK-1, MKN45, MKN28)
Hyp-PDT gave varying degrees of cell line sensitivity, narrow dosage differences enabled std. inhibitory $\left(\mathrm{ID}_{50}\right)$ values of between $0.15-0.22 \mathrm{~J} / \mathrm{cm}^{2}$ at $2.5 \mu \mathrm{M}$ hypericin for all.

Hyp-PDT comparisons indicated significant apoptotic cell death induction for both tissue types in a dose-dependent manner.

PDT with Hyp derivatives (improved hydrophilicity) revealed significant photocytotoxicities of all cell types. This was linked to those derivatives whose modifications improved cellular uptake. Hyp loading into polyactic acid/polyactic-co-glycolic acid nanoparticles revealed enhanced delivery and phototoxicity at lower drug loading percentages.

Hyp-PDT induced significant metabolic reductions coupled to excessive apoptosis with no population recovery observed over an 8 day period.

Hyp-PDT induced apoptosis occurring predominantly but not exclusively via the Fas/FasL receptor pathway. HYp-PDT induced apoptosis identified a wide range of gene clusters affected by ER oxidative stress. Hyp-PDT cell death was augmented by co-addition of metabolic reducing drugs against HER2, Akt, P-Erk1/2 and Survivin. A number of significant findings by the group of L.M. Davids revealed successful induction of cell death, even under the presence of melanin pigment. Collectively, authors reported the mechanisms of cell death to be different in each case thereby compounding the notion of multiple tissue treatments by a single PDT source.

Reported that the efficacy to induce apoptotic responses following proliferatory inhibition and cell cycle arrest hinged on uptake time and ALA-PDT dosage parameters.

Both Zawaka-Pankau et al., and Yow et al., studies attributed growth suppression and apoptosis to stimulation of pro-death p53 genes and mechanisms. Zawaka-Pankau et al., further linked this to PDT-induced disruption of the p53 negative regulator HDM2. ALA-PDT was reported to induce ER stress and the release of calmodulin resulting in dual apoptotic-autophagic responses. Reported that under individually established $\mathrm{IC}_{50}$ conditions for culture lines, either necrosis or apoptosis could be induced with no indications of PDT resistance between them.

Analysis of critical cellular parameters under $\mathrm{LD}_{50}$ conditions indicated that both tissue types were predominantly necrotic whilst RT4 cells displayed increased susceptibility. A complex study comparing low and high-dose ALA-PDT between culture lines reported similar gene upregulation for cell stress and cell cycle arrest and variable death responses across all culture lines.

Regarding metastatic potential, the study observed surviving populations to display lowered migration and invasiveness and reduced mitochondrial function. This they stated could be passed down to progenerator cells thereby aiding against metastasis. Comparisons revealed critical enzymes responsible for PpIX generation were also responsible for ALA-PDT susceptibility. Differential susceptibility between lines was due to high influx transporter and low efflux transporter protein levels. 
Table V. Continued

Metallo-

Phthalocyanines:

\section{Extensively}

researched,

with common

varieties harboring

core metal ions

aluminium $(\mathrm{AlPc})$,

silicon $(\mathrm{Pc} 4)$ and

zinc $(\mathrm{ZnPc})$. Due

to tendencies for

hydrophobicity

and self-aggregation,

peripheral sulfate

is a commonly

associated

modification

(265)

Pheophorbide a $(\mathrm{Pa})$ :

Natural macrocycle that is a product of chlorophyll degradation within plant systems. Attractive for PDT application due to its low toxicity and uncomplicated synthesis. (137)

\author{
AlPc-PDT: \\ Epidermoid \\ carcinoma (A431) \\ Oesophageal (SNO) \\ Breast (MCF-7)
}

Cervical:

Non-cancer (CHO-K1)

Carcinoma (HeLa)

Pc4-PDT:

Breast: Casp. 3

deficient (MCF-7),

Vector exp.

Casp. 3 (MCF-7/c3)

Breast (MCF-7)

Prostate (DU-145)

Melanoma:

Human (A375)

Murine (B16-F10)

Breast (MCF-7/c3)

ZnPc-PDT:

Lung (A549)

Oesophageal (SNO)

Breast (MCF-7)

Lung carcinoma

Breast (MCF-7)

Nasopharyngeal

carcinoma (KB)

Cervical (HeLa and $\mathrm{SiHe}$ )

Colon (HT29)

Liver resistant (R-HepG2)

Uterine (MES-SA)

Breast (MDA-MB-231)

Pancreatic adenocarcinoma Prostate (PC-3)

Prostate (PC-3M)

Epidermoid carcinoma (A431)

Non-cancer keratinocytes
Sulphonated AlPc-PDT induced both mitochondrial dysfunction associated with ATP loss and consequent cell death.

Within our laboratory, two separate studies comparing efficiencies of sulphonated AlPc with novel sulphonated GePc (germanium metal ion core) exhibited superior phototoxicity with AlPc regarding proliferation inhibition, metabolic retardation and cytotoxic responses leading to cell death. Comparisons of two AlPc derivatives bearing either chloride or tetrasulphonate chloride resulted in both derivatives inducing apoptotic cell death of HeLa whilst only cytoplasm and nuclear alterations in CHO-K1 cells unassociated with stress and death.

Following Pc4-PDT, authors observed presence of apoptotic caspase-3 to be of little consequence as both culture lines underwent photodamage of anti-apoptotic Bcl-2 and induction of cell death.

Reported routine induction of cell death in apoptotic deficient cell lines and that these deficiencies do not appear to prevent cell death by Pc4-PDT. Pc4-PDT efficiency reported to be augmented via enhanced silica nanoparticle encapsulation Ps delivery systems. This was observed for both tissue types exhibiting apoptotic responses.

Pc4 loaded into PEG-PCL micelles for delivery improved uptake and phototoxicity. Significant success indicated nanomedicine enhancements could benefit Pc4-PDT.

A comparative study indicated phototoxic responses and cell death across all tissue types at differential concentrations despite the initial priming of an adaptive response to ZnPc-PDT.

Multiple studies show lung carcinoma responding well to ZnPc-PDT via decreased population proliferation and DNA damage (Manoto \& Abrahamse) and that association within PCL nanoparticles enhances overall population cell death due to improved solubility (da Volta Soares, et al.).

A water-soluble $\mathrm{Zn}$ (II)Pc derivative induced an atypical apoptotic pathway as cell death markers were possibly linked to the involvement of calpains. Reported to undergo a form of caspase independent apoptosis in response to $\mathrm{ZnPc}-\mathrm{PDT}$.

Parallel studies with $\mathrm{ZnPc}$ both resulted in mitotic catastrophe responses along with cell cycle arrest and apoptosis.

$\mathrm{ZnPc}$ derivatives bearing diverse ionic charges were shown to hold efficient photoactivities where charges influenced membrane affinity.

Research group at The Chinese University of Hong Kong has reported on the effects of Pa-PDT including cell cycle arrest and late stage apoptosis at under $1 \mu \mathrm{M}$ dosage (Tang et al.), significant inductions of apoptosis via mitochondrial damage, singlet oxygen and intrinsic pathway mediators (Tang et al.), and induced mitochondrial-mediated apoptosis with dual loss of autophagy. This was achieved via ERK pathway suppression resulting in an anti-tumor effect (Bui-Xuan et al.). Reported mitochondrial damage and associated apoptosis following Pa-PDT. Reported autophagic induction which culminated in cell death over time. This was attributed to its prolonged activity which crippled cell function beyond recovery.

Using closely related pyropheophorbide; MPPa resulted in an apoptotic population majority suggesting subtle differences between a Ps and its derivatives may confer significant variations in death responses.

Comparison revealed greater survival inhibition of A431 epidermoid carcinoma cell over normal keratinocytes culminating in caspase-independent apoptosis further suggesting a cancer specificity by Pa-PDT. 
related studies, a wide variety of promising macrocycle Ps has imparted broad tissue-based susceptibility to PDT. A summary in Table V highlights this point across four well known Ps. Studies such as these have prompted many subsequent in vivo trials with hopes of establishing clinically viable modalities for each Ps. Examples of these are well described in the following list and represent but a small portion of the work done thus far (112-119).

5.2. Treatment of MDR Cancer Types. Therapeutic modalities are typically administered in triplicate-line regimens encompassing different molecular agents. Therapeutic resistance occurs when tumor cells exhibit defenses against these molecular agents (120). The level of resistance portrayed is related to the range of therapeutic recognition by the tumor cell. Resistance after exposure to one agent (1st-line of treatment) is termed "acquired resistance". Should the cancer cell exhibit additional resistance to unrelated agents (2nd- and 3rd-lines), this is termed "cross or multi-drug resistance" or $\operatorname{MDR}(22,66)$. The latter encompasses a broad range of unrelated therapeutic agents making it one of the principle causes for treatment inefficiency and relapse, thereby presenting a complicated obstacle to current therapeutics (120).

MDR imparts therapeutic incompatibility via either heightened protection or inactivation of fatal targets through manipulation of coordinated intracellular defense mechanisms (121). A principal facilitator associated with this phenotype is the drug efflux trans-membrane systems and their associated transporter proteins termed multi-drug resistance proteins (MRPs). These expel xenobiotic or harmful molecules from the cytoplasm in an ATP-dependent manner (122-124). As such, many highly mutagenic and kinetic cancer tissue types exhibit an over-expression or activation of these protein systems $(22,55,125,126)$. Of particular interest are the P-glycoprotein (P-gp) efflux systems that have been well documented over the years in association with cancer therapeutic resistance (80, 127-129). Encoded by the $A B C B 1$ gene and regulated by the protooncogene Ras (130), P-gp is alternatively known as ATPbinding cassette sub-family B member 1 (ABCB1), Multidrug resistance protein 1 (MDR1) or cluster of differentiation 243 (CD243). Bound within the plasma membrane, P-gp has a broad substrate specificity allowing for recognition and expulsion of multiple xenobiotic components of dissimilar structures via a unique binding pocket. Associated conformational changes are driven by ATP hydrolysis (124, $126,128,131,132)$.

PDT has been suggested to potentially overcome MDR by either knocking-down drug efflux activities or through suggested non-recognition of the Ps for removal (120). An extensive review by Detty et al., (2004) (133) briefly touched on this concept by stating that whether drug efflux systems recognized Ps structures for removal or not could be mutually beneficial. Non-recognition would allow successful PDT administration to the cell without efflux interference whilst recognition could result in PDT damage of the efflux systems thereby enabling increased efficiency of other therapeutics. Indeed, some early studies highlighted sufficient accumulation of macrocycle Ps classes within a range of cell types despite P-gp expression $(134,135)$. These studies also reported knockdown of resistance to chemotherapeutic drugs and an indication that MDR phenotypes may not express cross-resistance to PDT. This potential has also been carried over to second generation macrocycles including; mTHPC-PDT on doxorubicinresistant MCF-7 cells (136), Pheophorbide a (Pa)-PDT on RHepG2 cells bearing MDR activity (137), and phthalocyanine (AISPc)-PDT on colchicine-resistant 3T3 cells (138).

Whilst this is promising for P-gp efflux evasion, there are related transport systems also associated with cancer development and drug resistance. These most commonly include the ATP-binding cassette sub-family G member 2 (ABCG2) also known as the Breast cancer resistance protein (BCRP) (139) and the ATP-binding cassette sub-family C member 1 (ABCC1) also known as Multidrug resistanceassociated Protein 1 (MRP1) (140). In particular, BCRP has been shown to exhibit active substrate recognition for a variety of photosensitizers including; $\mathrm{Pa}$ (141), Pa methyl ester (MPPa), Clorin e6, ALA (142, 143), HPPH (144, 145), and Photofrin (146).

To curb this, more recent studies report on combination treatments with various BCRP drug efflux inhibitors. Of these, tyrosine kinase inhibitors have become popular since the success of Imatinib Mesylate (commercially known as Gleevec $^{\circledR}$ ) as a chemotherapeutic (147). Extension of their inhibitory effects to overcome MDR has been extensively explored (148) and a few studies have extended this concept to prevent Ps efflux during PDT $(144,145,149)$. Likewise, similar PDT enhancements have also been reported using alternative inhibitors such as microbial metabolites; Fumitremorgin $\mathrm{C}$ and its analog Ko-134 as well as proadifen against both the ABCG2 and P-gp efflux systems $(146,150,151)$.

Unfortunately this approach, whilst effective, is not considered ideal. Whilst there are many therapeutic agents available for drug efflux transporter inhibition $(151,152)$, many have been shown to harbor low selectivity and therefore reduced potency as well as significant contraindications for the necessary release of toxic metabolites and complicated co-treatment dosage adjustments between themselves and chemotherapeutic agents (153). This has been demonstrated in a few in vivo trials which have reported Imanitib Mesylate and some related inhibitors to bear severe toxicities including hypertension, oesophagitis, gastritis and cardiotoxicity (154-156). 
Table VI. Summary of current macrocycle Ps approved for clinical trials and adjuvant therapies. For each, definitive aspects highlighting reasons for their success are given. Additionally, cancer types and other tissue disorders under application are listed.

\begin{tabular}{|c|c|c|c|c|}
\hline Macrocycle Ps & & Therapeutic Traits & Clinical Applications & Ref. \\
\hline Porphyin Class: & $\begin{array}{l}\text { Photofrin }{ }^{\mathrm{TM}} \\
\text { (Porphyrin mixture) }\end{array}$ & $\begin{array}{l}\text { Comprised of a mixture of active } \\
\text { porphyrin oligomers linked } \\
\text { by ether and ester functional groups }\end{array}$ & $\begin{array}{l}\text { Cancers treated: breast, malignant and } \\
\text { non-malignant cervical, bladder, } \\
\text { oesophageal, and various types and } \\
\text { stages of lung and gastric cancer }\end{array}$ & $\begin{array}{l}133 \\
162 \\
237 \\
286\end{array}$ \\
\hline \multirow[t]{4}{*}{ Chlorin Class: } & $\begin{array}{l}\text { Foscan }{ }^{\circledR} / \text { Temoporfin } \\
\text { (meso-Tetrahydroxy- } \\
\text { phenylchlorin) }\end{array}$ & $\begin{array}{l}\text { Synthetic chlorin, lipophilic. } \\
\text { High }{ }^{1} \mathrm{O}_{2} \text { quantum yield }\end{array}$ & $\begin{array}{l}\text { Approved for PDT of head and } \\
\text { neck cancer. Clinical trials: ovary-, } \\
\text { breast-, prostate-, esophageal-, } \\
\text { lung-, gastric- and skin cancers }\end{array}$ & \\
\hline & $\begin{array}{l}\text { Tookad }^{\circledR} \\
\text { (Pd(II)bacteriopheophorbide } \\
\text { derivative) }\end{array}$ & $\begin{array}{l}\text { Lipophilic with exceptional }{ }^{1} \mathrm{O}_{2} \\
\text { quantum yield due to } \\
\text { the heavy-atom effect. }\end{array}$ & Phase III clinical trials for prostate cancer & $\begin{array}{c}85 \\
162 \\
165 \\
240\end{array}$ \\
\hline & $\begin{array}{l}\text { Photochlor } \\
\text { (pheophorpbide: HPPH) }\end{array}$ & Lipophilic & $\begin{array}{l}\text { Clinical trials: oesophageal cancer, } \\
\text { Barrett's oesophagus, BCC and lung cancer }\end{array}$ & $\begin{array}{l}288 \\
287\end{array}$ \\
\hline & $\begin{array}{l}\text { Verteporfin (VP) } \\
\text { (Benzoporphyrin derivative- } \\
\text { monoacid ring A: BpD-MA) }\end{array}$ & $\begin{array}{l}\text { High }{ }^{1} \mathrm{O}_{2} \text { quantum yield } \\
\text { High efficacy allows } \\
\text { for lower dosages }\end{array}$ & $\begin{array}{l}\text { Approved for age related macular degeneration } \\
\text { Clinical trials: leukemic bone marrow } \\
\text { purging, ocular disease, human psoriasis, } \\
\text { lung- and bladder cancer, canine osteosarcoma }\end{array}$ & \\
\hline $\begin{array}{l}\text { Hydroxy- } \\
\text { quionone Class: }\end{array}$ & $\begin{array}{l}\text { Levulan }^{\mathrm{TM}} \\
\text { (ALA porphycene) } \\
\text { Hexvix }^{\mathrm{TM}} \text { and } \\
\text { (ALA ester) } \\
\text { Metvix }^{\mathrm{TM}} \\
\text { (MAL) }\end{array}$ & $\begin{array}{l}\text { Precursor compounds utilizing } \\
\text { heme synthesis pathways for } \\
\text { generation of Protoporphyrin X }\end{array}$ & $\begin{array}{l}\text { Treatment of pre-cancerous actinic keratosis. } \\
\text { Detection: various neoplasms of the brain, } \\
\text { oesophagus, bladder, uterus and skin } \\
\text { Detection of papillary bladder cancer }\end{array}$ & $\begin{array}{c}92 \\
162\end{array}$ \\
\hline $\begin{array}{l}\text { Phthalocyanine } \\
\text { Class: }\end{array}$ & $\begin{array}{l}\text { Photosense }^{\circledR} \\
\text { (Sulphonated Aluminium } \\
\text { Phthalocyanine) }\end{array}$ & $\begin{array}{l}\text { Constitutes a mixture of di- and } \\
\text { tri-sulphonic derivatives collectively } \\
\text { exhibiting the largest molar absorption } \\
\text { coefficient }\left(\varepsilon=20 \times 10^{4} \mathrm{M}^{-1} \mathrm{~cm}^{-1}\right) \\
\text { of all } 2 \text { nd generation Ps }\end{array}$ & $\begin{array}{l}\text { Phase III clinical trials: SCC of skin, } \\
\text { breast, oropharyngeal, lung and larynx }\end{array}$ & 162 \\
\hline Texaphyrin Class: & $\begin{array}{l}\text { Xcytrin }{ }^{\mathrm{TM}} \text { and Motexafin } \\
\text { (Gd(III) texaphyrins) }\end{array}$ & $\begin{array}{l}\text { Large internal cores enable complexing } \\
\text { with many trivalent metal ions }\end{array}$ & $\begin{array}{l}\text { Currently used as MRI agents, } \\
\text { radiosensitizers and chemosensitizers. } \\
\text { Phase III clinical trials: brain tumors } \\
\text { and metastases is underway } \\
\text { Approved for PDT of prostate- and } \\
\text { cervical- cancers. Clinical trials: breast } \\
\text { cancer, melanoma and Kaposi's sarcoma }\end{array}$ & $\begin{array}{l}162 \\
223 \\
289\end{array}$ \\
\hline
\end{tabular}

A promising alternative is the association of Ps with nanoparticles. This combination has been widely investigated and found to aid PDT greatly via targeted delivery, increased uptake concentrations and retention times, shielding of drug recognition and efflux as well as inducing an occasional Photochemical internalization (PCI) effect when the nanoparticle complexes are stored within the cells lysosomal compartments. Studies are extensive and in surplus prompting the release of many comprehensive reviews on the field (157-160). Ranging from silica nanoparticles and block co-polymers to polymeric micelles and dendrimers, the intricacy and extensiveness of this field is beyond the scope of this review but hold much promise against MDR.

5.3. Current Applications of Macrocycles within Clinical PDT for Cancer. Due to its research advancements, PDT with certain Ps are clinically available in some countries alone or as adjuvant therapy to traditional treatments, 
applicable for multiple small or superficial cancerous tumors and certain non-malignant pathologies characterized by cellular overgrowth $(85,90,161,162)$. The range of macrocycle Ps utilized span the multiple subclasses described in Table $\mathrm{V}$ and are briefly highlighted for their applications in Table VI.

\section{PDT Shortcomings and Focal Points of Consideration}

Like any therapeutic, PDT is far from a perfect process demonstrating its own limitations for effect however. A few limitations regarding PDT include;

- Selective recognition of certain Ps structures by drug efflux systems reduces cancer cell concentration and retention time thereby weakening PDT toxicities,

- Clinical association with local inflammatory pain. Higher nerve density augments this however the main cause is not well understood,

- Excitation light is scattered and absorbed by tissue macromolecules thereby reducing dosages available for subcutaneous PDT,

- Currently, only static cancer can be treated effectively. Disseminated tumors, leukemias and lymphomas require a remodeled approach for PDT administration,

- Of major concern, many Ps exhibit hydrophobic natures incurring considerable aggregation within aqueous environments. This lowers systemic administration and photoactivity.

In free form, mode of Ps uptake is closely associated with a complex coordination of properties regarding size, charge, lipo-/hydro-philicity, aggregation state and cell type (163166). Requirement of a balanced hydro- and lipophilicity enabling dual biocompatibility with aqueous biological solutions and lipid membranes has placed focus on Ps peripheral modification. Whether it is the addition of simple functional groups $\left(e . g . \mathrm{SO}_{4}\right)$ or large long chain or bulky substituents, these are commonplace facilitators of solubility, with the added benefit of increasing targeted uptake and redirected subcellular localization (167-171). Adversely, associations with nanoparticle drug delivery systems have become a promising solution to many of these structural flaws.

Despite these drawbacks, PDT remains a promising alternative to current therapies. Its overall efficiency is multifactorial with respect to tissue, Ps and light properties. Tissue properties including fluctuations in composition, tumor depth/type, extent of microvasculature, cell cycle phase, cellular metabolic state, cellular concentration of molecular oxygen, ROS production yield and type and duration of inflammatory and immune responses are all unalterable. It is therefore necessary that Ps properties (type, tissue accumulation potential, intracellular localization, absorption spectrum, and total dosage) and light properties (source, fluence rate, wavelength, and depth of tissue penetration) are manipulated to compensate for a suboptimal PDT environment $(88,120,172-175)$. As such, research efforts are being made to improve the overall effect of PDT in order to gain a solid standing in the therapeutic field.

\section{References}

1 Hart IR: Biology of cancer. Medicine 32(3): 1-5, 2004.

2 Haber DA: Molecular Genetics of Cancer: Oncogenes and ProtoOncogenes., 2006. Available from: http://www.medscape.com/ viewarticle/534487 [last accessed 18 February 2016].

3 McCormick F: Signaling networks that cause cancer. Trends Cell Biol 9(12): M53-56, 1999.

4 Cahill DP, Kinzler KW, Vogelstein B and Lengauer C: Genetic instability and Darwinian selection in tumors. Trends Cell Biol 9(12): M57-60, 1999.

5 Garay RP, Viens P, Bauer J, Normier G, Bardou M, Jeannin JF and Chiavaroli C: Cancer relapse under chemotherapy: why TLR2/4 receptor agonists can help. Eur J Pharmacol 563: 1-17, 2007.

6 Doucas H and Berry DP: Basic principles of the molecular biology of cancer I. Surgery 24(2): 43-7, 2006.

7 Bertram JS: The molecular biology of cancer. Mol Aspects Med 21(6): 167-223, 2000.

8 Hanahan D and Weinberg RA: Hallmarks of cancer: The next generation. Cell 144: 646-674, 2011.

9 Palmieri D, Chambers AF, Felding-Habermann B, Huang S and Steeg PS: The biology of metastasis to a sanctuary site. Clin Cancer Res 13(6): 1656-1662, 2007.

10 Ward PS and Thompson CB: Metabolic reprogramming: A cancer hallmark even Warburg did not anticipate. Cancer Cell 21: 297-308, 2012.

11 Wu T-L and Zhou D: Viral delivery for gene therapy against cell movement in cancer. Adv Drug Deliv Rev 63: 671-677, 2011.

12 Chollet A, Hohl D and Perrier P: Risk of cutaneous squamous cell carcinomas: the role of clinical and pathological reports. Rev Med Suisse 8(335): 743-746, 2012.

13 Marks R: Squamous cell carcinoma. Lancet 347(9003): 735 738, 1996.

14 Miller SJ, Alam M, Andersen J, Berg D, Bichakjian CK, Bowen G, Cheney RT, Glass LF, Grekin RC, Kessinger A, Lee NY, Liegeois N, Lydiatt DD, Michalski J, Morrison WH, Nehal KS, Nelson KC, Nghiem P, Olencki T, Perlis CS, Rosenberg EW, Shaha AR, Urist MM, Wang LC and Zic JA: Basal cell and squamous cell skin cancers. J Natl Compr Canc Netw 8(8): 836-864, 2010.

15 Casari A, Pellacani G, Seidenari S, Cesinaro AM, Beretti F, Pepe $\mathrm{P}$ and Longo C: Pigmented nodular basal cell carcinomas in differential diagnosis with nodular melanomas: confocal microscopy as a reliable tool for in vivo histologic diagnosis. J Skin Cancer 2011: 406859, 2011.

16 Popadić M: Dermoscopic features in different morphologic types of basal cell carcinoma. Dermatol Surg 40(7): 725-732, 2014.

17 Wong CSM, Strange RC and Lear JT: Basal cell carcinoma. BMJ 327(7418): 794-798, 2003. 
18 Bond-Smith G, Banga N, Hammond TM and Imber CJ: Pancreatic adenocarcinoma. BMJ 344: e2476, 2012.

19 Dennis JL, Hvidsten TR, Wit EC, Komorowski J, Bell AK, Downie I, Mooney J, Verbeke C, Bellamy C, Kieth WN and Oien KA: Markers of adenocarcinoma characteristic of the site of origin: development of a diagnostic algorithm. Clin Cancer Res 11(10): 3766-3772, 2005.

20 Hammar S: Metastatic adenocarcinoma of unknown primary origin. Hum Pathol 29(12): 1393-402, 1998.

21 Lygidakis NJ, Jain $\mathrm{S}$, Sacchi $\mathrm{M}$ and Vrachnos $\mathrm{P}$ : Adenocarcinoma of the pancreas- Past, present and future. Hepatogastroenterology 52(64): 1281-1292, 2005.

22 Coley HM: Mechanisms and strategies to overcome chemotherapy resistance in metastatic breast cancer. Cancer Treat Rev 34(4): 378-390, 2008.

23 Sharman WM, van Lier JE and Allen CM: Targeted photodynamic therapy via receptor mediated delivery systems. Adv Drug Deliv Rev 56: 53-76, 2004.

24 Corrie PG and Pippa G: Cytotoxic chemotherapy: clinical aspects. Medicine 36(1): 24-28, 2008.

25 Malhotra V and Perry MC. Classical chemotherapy: mechanisms, toxicities and the therapeutic window. Cancer Biol Ther 2(4 Suppl 1): S2-4, 2003.

26 Stewart DJ, Chiritescu G, Dahrouge S, Banerjee S and Tomiak EM: Chemotherapy dose-response relationships in non-small cell lung cancer and implied resistance mechanisms. Cancer Treat Rev 33: 101-137, 2007.

27 Bold RJ, Termuhlen PM and McConkey DJ: Apoptosis, cancer and cancer therapy. Surg Oncol 6(3): 133-142, 1997.

28 Palucka K and Banchereau J: Dendritic-cell-based therapeutic cancer vaccines. Immunity 39(1): 38-48, 2013.

29 Sherbenou DW, Behrens CR, Su Y, Wolf JL, Martin TG 3rd and Liu B: The development of potential antibody-based therapies for myeloma. Blood Rev 29(2): 81-91, 2015.

30 Murray LJ and Robinson MH: Radiotherapy: Technical aspects. Medicine 39: 698-704, 2011.

31 Akudugu JM and Howell RW: A method to predict response of cell populations to cocktails of chemotherapeutics and radiopharmaceuticals: Validation with daunomycin, doxorubicin, and the alpha particle emitter 210Po. Nucl Med Biol 39(7): 954-961, 2012.

32 Schleicher UM, Phonias C, Spaeth J, Schlöndorff G, Ammon J and Andreopoulos D: Intraoperative radiotherapy for preirradiated head and neck cancer. Radiother Oncol 58(1): 77-81, 2001.

33 Song $\mathrm{H}$ and Sgouros G: Radioimmunotherapy of solid tumors: searching for the right target. Curr Drug Deliv 8: 26-44, 2011.

34 Michel RB, Andrews PM, Castillo ME and Mattes MJ: In vitro cytotoxicity of carcinoma cells with 111In-labeled antibodies to HER-2. Mol Cancer Ther 4: 927-937, 2005.

35 Vaidya JS, Wenz F, Bulsara M, Tobias JS, Joseph DJ, Keshtgar M, Flyger HL, Massarut, S, Alvarado M, Saunders C, Eiermann W, Metaxas M, Sperk E, Sütterlin M, Brown D, Esserman L, Roncadin M, Thompson A, Dewar JA, Holtveg HMR, Pigorsch S, Falzon M, Harris E, Matthews A, Brew-Graves C, Potyka I, Corica T, Williams NR and Baum M: Risk-adapted targeted intraoperative radiotherapy versus whole-breast radiotherapy for breast cancer: 5-year results for local control and overall survival from the TARGIT-A randomised trial. The Lancet 383(9917): 603-613, 2013.
36 Greco O and Dachs GU: Gene directed enzyme/prodrug therapy of cancer: historical appraisal and future prospectives. J Cell Physiol 187(1): 22-36, 2001.

37 Gore ME and Johnston SRD: Biology of cancer; Clinical applications. Medicine 32(3): 6-11, 2004.

38 Ramesh R, Saeki T, Templeton NS, Ji L, Stephens LC, Ito I, Wilson DR, Wu Z, Branch CD, Minna JD and Roth JA: Successful treatment of primary and disseminated human lung cancers by systemic delivery of tumor suppressor genes using an improved liposome vector. Mol Ther 3(3): 337-350, 2001.

39 Abe A, Ikawa H, Muguruma H and Maeda Y: Secondary myelodysplasia and leukemia following carboplatin and paclitaxel-containing chemotherapy for ovarian cancer. Gan To Kagaku Ryoho 35(10): 1795-1798, 2008.

40 Mukherjea D and Rybak LP: Pharmacogenomics of cisplatininduced ototoxicity. Pharmacogenomics 12(7): 1039-1050, 2011.

41 Rodgers GM 3rd, Becker PS, Bennett CL, Cella D, ChananKhan A, Cleeland C, Coccia PF, Djulbegovic B, Gilreath JA, Kraut EH, Matulonis UA, Millenson MM, Reinke D, Rosenthal J, Schwartz RN, Soff G, Stein RS, Vlahovic G and Weir AB 3rd: Cancer- and chemotherapy-induced anemia. J Natl Compr Canc Netw 6(6): 536-564, 2008.

42 Thatisshetty AV, Agresti N and O'Brien CB: Chemotherapyinduced hepatoxicity. Clin Liver Dis 17(4): 671-686, 2013.

43 Gafter-Gvili A, Fraser A, Paul M, Vidal L, Lawrie TA, van de Wetering MD, Kremer LCM and Leibovici L: Antibiotic prophylaxis for bacterial infections in afebrile meutropenic patients following chemotherapy. Cochrane Database Syst Rev 1: CD004386, 2012.

44 Sahni V, Choudhury D and Ahmed Z: Chemotherapy-associated renal dysfunction. Nat Rev Nephrol 5(8): 450-462, 2009.

45 Shakih AY and Shih JA: Chemotherapy-induced cardiotoxcity. Curr Heart Fail Rep 9(2): 117-127, 2012.

46 Lawrence YR, XA Li, el Naqa I, Hahn CA, Marks LB, Merchant TE and Dicker AP: Radiation dose-volume effects in the brain. Int J Radiat Oncol Biol Phys 76(3 Suppl): S20-27, 2010.

47 Meek AG: Breast radiation therapy and lymphedema. Cancer 83(12 Suppl American): 2788-2797, 1998.

48 Sheehan JP, Shaffrey ME, Gupta B, Larner J, Rich JN and Park DM: Improving the radiosensitivity of radioresistant and hypoxic glioblastoma. Future Oncol 6(10): 1591-1601, 2010.

49 Lee VH, Ng SC, Leung TW, Au GK and Kwong DL: Dosimetric predictors of radiation-induced acute nausea and vomiting in IMRT for nasopharyngeal cancer. Int J Radiat Oncol Biol Phys 84(1): 176-182, 2012.

50 Murthy R, Brown DB, Salem R, Meranze SG, Coldwell DM, Krishnan S, Nunez $R$ and Habbu A: Gastrointestinal complications associated with hepatic arterial Yttrium-90 microsphere therapy. J Vasc Interv Radiol 18(4): 553-561, 2007.

51 Carretero C, Munoz-Navas M, Betes M, Angos R, Subtil JC, Fernandez-Urien I, De la Riva S, Sola J, Bilbao JL, de Luis and, Sangro B: Gastroduodenal injury after radioembolization of hepatic tumors. Am J Gastroenterol 102(6): 1216-1220, 2007.

52 Wright JD, St Clair CM, Deutsch I, Burke WM, Gorrochurn P, Sun $\mathrm{X}$ and Herzong TJ: Pelic radiotherapy and the risk of secondary leukemia and multiple myeloma. Cancer 116(10): 2486-2492, 2010. 
53 Burke J: Virus therapy for bladder cancer. Cytokine Growth Factor Rev 21: 99-102, 2010.

54 Rouschop KM, Dubois LJ, Keulers TG, van den Beucken T, Lambin P, Bussink J, van der Kogel AJ, Koritzinsky M and Wouters BG: PERK/elF2 $\alpha$ signaling protects therapy resistant hypoxic cells through induction of glutathione synthesis and protection against ROS. PNAS 110(12): 4622-4627, 2013.

55 Tokunaga E, Kataoka A, Kimura Y, Oki E, Mashino K, Nishida K, Koga T, Morita M, Kakeji Y, Baba H, Ohno S and Maehara $\mathrm{Y}$ : The association between Akt activation and resistance to hormone therapy in metastatic breast cancer. Eur J Cancer 42: 629-635, 2006

56 Lundholm L, Haag P, Zong D, Juntti T, Mörk B, Lewensohn R and Viktorsson K: Resistance to DNA-damaging treatment in non-small cell lung cancer tumor-initiating cells involves reduced DNA-PK?ATM activation and diminished cell cycle arrest. Cell Death Dis 4: e478, 2013

57 Oliver TG, Mercer KL, Sayles LC, Burke JR, Mendus D, Lovejoy KS, Cheng MH, Subramanian A, Mu D, Powers S, Crowley D, Bronson RT, Whittaker CA, Bhutkar A, Lippard SJ, Golub T, Thomale J, Jacks T and Sweet-Cordero EA: Chonic cisplatin treatment promotes enhanced damage repair and tumor progression in a mouse model of lung cancer. Genes Dev 24: 837-852, 2010

58 Sen B, Peng S, Woods DM, Wistuba I, Bell D, El-Naggar AK, Lai SY and Johnson FM: STAT5A-mediated SOCS2 expression regulates Jak2 and STAT3 activity following c-Src inhibition in head and neck squamous carcinoma. Clin Cancer Res 18(1): 127-139, 2012

59 von Manstein V, Yang CM, Richter D, Delis N, Vafaizadeh V and Bernd G: Resistance of cancer cells to targeted therapies through the activation of compensating signaling loops. Curr Signal Transduc Ther 8(3): 193-202, 2013.

60 Citron ML, Berry DA, Cirrincione C, Hudis C, Winer EP, Gradishar WJ, Davidson NE, Martino S, Livingston R, Ingle JN, Perez EA, Carpenter J, Hurd D, Holland JF, Smith BL, Sartor CI, Leung EH, Abrams J, Schilsky RL, Muss HB and Norton L: Randomized trial of dose-dense versus conventionally scheduled and sequential versus concurrent combination chemotherapy as postoperative adjuvant treatment of node-positive primary breast cancer: First report of intergroup trial C9741/Cancer and leukemia group B tiral 9741. J Clin Oncol 21(8): 1431-1439, 2003.

61 Costantini DL, Villani DF, Vallis KA and Reilly RM: Methotrexate, paclitaxel, and doxorubicin radiosensitize HER2amplified human breast cancer cells to the Auger electronemitting radiotherapeutic agent ${ }^{111}$ In-NLS-Trastuzumab. J Nucl Med 51: 477-483, 2010.

62 Falchook GS, Moulder SL, Wheler JJ, Jiang Y, Bastida CC and Kurzrock R: Dual HER2 inhibition in combination with antiVEGF treatment is active in heavily pretreated HER2-positive breast cancer. Ann Oncol 24(12): 3004-3011, 2013.

63 Hashiguchi T, Nasu M, Hashimoto T, Kuniyasu T, Inoue H, Sakai N, Ouchi K, Amano T, Isayama F, Tomita M, Iwnauma Y, Tsurumaru M and Kajiyama Y: Docetaxel, cisplatin and 5fluorouracil adjuvant chemotherapy following three-field lymph node dissection for stage II/III N1, 2 esophageal cancer. Mol Clin Oncol 2: 719-724, 2014.

64 van Hagen P, Hulshof MCCM, van Lanschot JJB, Steyerberg EW, van Berge Henegouwen MI, Wijnhoven BP, Richel DJ,
Nieuwenhuijzen GA, Hospers GA, Bonenkamp JJ, Cuesta MA, Blaisse RJ, Busch OR, ten Kate FJ, Creemers GJ, Punt CJ, Plukker JT, Verheul HM, Spillenaar Bilgen EJ, van Dekken H, van der Sangen MJ, Rozema T, Biermann K, Beukema JC, Piet AH, van Rij CM, Reinders JG, Tilanus HW and van der Gaast A: Preoperative chemoradiotherapy for esophageal or junctional cancer. N Engl J Med 366(22): 2074-2084, 2012.

65 Bussels B, Maes A, Hermans R, Nuyts S, Weltens C and Van den Bogaert W: Recurrences after conformal parotoid-sparing radiotherapy for head and neck cancer. Radiother Oncol 72(2): 119-127, 2004.

66 Alakhova DY and Kabanov AV: Pluronics and MDR reversal: An update. Mol Pharm 11(8): 2566-2578, 2014.

67 Zbytek B, Carlson JA, Granese J, Ross J, Mihm MC Jr and Slominski A: Current concepts of metastasis in melanoma Expert Rev Dermatol 3: 569-585, 2008.

68 Castells M, Thibault B, Delord JP and Couderc B: Implication of tumor microenvironment in chemoresistance: tumorassociated stomal cells protect tumor cells from death. Int J Mol Sci 13(8): 9545-9571, 2012

69 Creighton CJ, Li X, Landis M, Dixon JM, Neumeister VM, Sjolund A, Rimm DL, Wong H, Rodriguez A, Herschkowitz JI, Fan C, Zhang X, He X, Pavlick A, Gutierrez MC, Renshaw L, Larionov AA, Faratian D, Hilsenbeck SG, Perou CM, Lewis MT, Rosen JM and Chang JC: Residual breast cancers after conventional therapy display mesenchymal as well as tumorinitiating features. PNAS 106(33): 13820-13825, 2009.

70 Sebens $\mathrm{S}$ and Shafer H: The tumor stroma as mediator of drug resistance-a potential target to improve cancer therapy? Curr Pharm Biotechnol 13(11): 2259-2272, 2012.

71 Singh A and Settleman J: EMT, cancer stem cells and drug resistance: an emerging axis of evil the war on cancer. Oncogene 29: 4741-4751, 2010.

72 Zoeller JJ, Bronson RT, Gilmer TM, Selfors LM, Lu Y, Apple SK, Press MF, Hurvitz SA, Slamon DJ, Mills GB and Brugge JS: Basement membrane localized tumor cells are protected from HER2-targeted therapy in vivo. Cancer Res 72(24 Suppl): Abstract nr P4-08-05, 2012.

73 Lorenzo GD, Buonerba C and Kantoff PW: Immunotherapy for the treatment of prostate cancer. Nat Re Clin Oncol 8: 551-561, 2011

74 Mazzaglia A, Bondi ML, Scala A, Zito F, Barbieri G, Crea F, Vianelli G, Mineo P, Fiore F, Pellerito C, Pellerito L and Costa MA: Supramolecular assemblies based on complexes of nonionic amphiphilic cyclodextrins and a meso-tetra(4sulfonatophenyl)porphine tributyltin(IV) derivative: Potential nanotherapeutics against melanoma. Biomacromolecules 14 : 3820-3829, 2013

75 Arlt MJ, Walters DK and Banke IJ: The antineoplastic antibiotic taurolidine promotes lung and liver metastasis in two syngenic osteosarcoma mouse models and exhibits severe liver toxicity. Int J Cancer 131(5): E804-812, 2012.

76 Mimeault $M$ and Batra SK: New advances on critical implications of tumor- and metastasis-initiating cells in cancer progression, treatment resistance and disease recurrence. Histol Histopathol 25(8): 1057-1073, 2010.

77 Volk-Draper L, Hall K, Griggs C, Rajput S, Kohio P, DeNardo $\mathrm{D}$ and Ran S: Paclitaxel therapy promotes breast cancer metastasis in a TRL4-Dependent manner. Cancer Res 74(19): 5421-34, 2014. 
78 Scott AM, Wolchock JD and Old LJ: Antibody therapy in cancer. Nat Rev Cancer 12(4): 278-287, 2012.

79 Devarajan E, Sahin AA, Chen JS, Krishnamurthy RR, Aggarwal N, Brun AM, Sapino A, Zhang F, Sharma D, Yang XH, Tora $\mathrm{AD}$ and Mehta K: Down-regulation of caspase 3 in breast cancer: a possible mechanism for chemoresistance. Oncogene 21: 8843-8851, 2002.

80 Paredes Lario A, García CB, Elizondo ME and Lobo C: Expression of proteins associated with multidrug resistance and resistance to chemotherapy in lung cancer. Arch Bronconeumol 43(9): 479-484, 2007.

81 Chen W-Y: Cancer Acquired Resistance: A new lesson from chronic myelogenous leukemia.J Bone Marrow Res 1: e101, 2013.

82 Azim H, de Azambuja E, Colozza M, Bines and Piccart MJ: Long-term toxic effects of adjuvant chemotherapy in breast cancer. Ann Oncol 22(9): 1939-1947, 2011.

83 Daniëls LA, Krol ADG, Schaapveld M, Putter H, Jansen PM, Marijt EW, van Leeuwen FE and Creutzberg CL: Long-term risk of secondary skin cancers after radiation therapy for Hodgkin's Lymphoma. Radiother Oncol 109(1): 140-145, 2013.

84 Holohan C, van Schaeybroeck A, Longley DB and Johnston PG: Cancer drug resistance: an evolving paradigm. Nat Rev Cancer 13(10): 714-726, 2013.

85 Allison RR and Sibata CH: Oncologic photodynamic therapy photosensitizers: A clinical review. Photodiag Photodyn Ther 7: 61-75, 2010.

86 Kessel D: Death pathways associated with photodynamic therapy. Med Laser App 21(4): 219-224, 2006.

87 Bonneau S, Morlière P and Brault D: Dynamics of interactions of photosensitizers with lipoproteins and membrane-models: correlation with cellular incorporation and subcellular distribution. Biochem Pharmacol 68(7): 1443-1452, 2004.

88 Castano AP, Demidova TN and Hamblin MR: Mechanisms in photodynamic therapy: Part one - Photosensitizers, photochemistry and cellular localization. Photodiag Photodyn Ther 1: 279-293, 2004.

89 Dougherty TJ, Gomer CJ, Henderson BW, Jori G, Kessel D, Korbelik M, Moan J and Peng Q: Photodynamic therapy. J Natl Cancer 90(12): 889-905, 1998.

90 Josefsen LB and Boyle RW: Photodynamic therapy and the development of metal-based photosensitizers. Metal Based Drugs 2008: 276109, 2008.

91 Nyman ES and Hynninen PH: Research advances in the use of tetrapyrrolic photosensitizers for photodynamic therapy. J Photochem Photobiol B: Biol 73: 1-28, 2004.

92 Blázquez-Castro A, Carrasco E, Calvo MI, Jaén P, Stockert JC, Juarranz A, Sanz-Rodriquez F and Espada J: Protoporphyrin IX-dependent photodynamic production of endogenous ROS stimulates cell proliferation. Eur J Cell Biol 91: 216-223, 2012.

93 Chen Y-K, Senadi GC, Lee C-H, Tsai Y-M, Chen Y-R, Hu WP, Chou Y-W, Kuo K-K and Wang J-J: Apoptosis Induced by 2Aryl Benzothiazoles-Mediated Photodynamic Therapy in Melanomas via Mitochondrial Dysfunction. Chem Res Toxicol 27: 1187-1198, 2014.

94 Ismail AFM, Ali MM and Ismail LFM: Photodynamic therapy mediated antiproliferative activity of some metal-doped $\mathrm{ZnO}$ nanoparticles in human liver adenocarcinoma HepG2 cells under UV irradiation. J Photochem Photobiol B: Biol 138: 99108,2014
95 Bandyopadhyay U, Das D and Banerjee RK: Reactive oxygen species: Oxidative damage and pathogenesis. Curr Sci 77(5): 658-666, 1999.

96 Zong W-X and Thompson CB: Necrotic death as a cell fate. Genes Dev 20: 1-15, 2006.

97 Cooke MS, Evans MD, Dizdaroglu M and Lunec J: Oxidative DNA damage: mechanisms, mutation and disease. FASEB J 17: 1195-1214, 2003.

98 Franco R, Schoneveld O, Georgakilas AG and Panayiotidis MI: Oxidative stress, DNA methylation and carcinogenesis. Cancer Lett 266: 6-11, 2008.

99 Haklar G, Sayin-Ozveri E, Yuksel M, Aktan AO and Yalçin AS: Different kinds of reactive oxygen and nitrogen species were detected in colon and breast tumors. Cancer Lett 165: 219-224, 2001.

100 Hurt EM, Thomas SB, Peng B and Farrar WL: Integrated molecular profiling of SOD2 expression in multiple myeloma. Blood 109(9): 3953-3962, 2007.

101 Nordberg J and Arnér ES: Reactive oxygen species, antioxidants, and the mammalian thioredoxin system. Free Radic Biol Med 31(11): 1287-1312, 2001.

102 Bostwick DG, Alexander EE, Singh R, Shan A, Qian J, Santella RM, Oberley LW, Yan T, Zhong W, Jiang H and Oberley TD: Antioxidant Enzyme Expression and Reactive Oxygen Species Damage in Prostatic Intraepithelial Neoplasia and Cancer. Cancer 89(1): 123-134, 2000.

103 Davids LM and Kleemann B: Combating melanoma: The use of photodynamic therapy as a novel, adjuvant therapeutic tool. Cancer Treat Rev 37: 465-475, 2011.

104 Glorieux C, Dejeans N, Sid B, Beck R, Calderon PB and Verrax $\mathrm{J}$ : Catalase overexpression in mammary cancer cells leads to a less aggressive phenotype and an altered response to chemotherapy. Biochem Pharmacol 82: 1384-1390, 2011.

105 Toyokuni S, Okamoto K, Yodoi J and Hiai H: Persistent oxidative stress in cancer. FEBS Lett 358: 1-3, 1995.

106 Sun Y: Free radicals, antioxidant enzymes, and carcinogenesis. Free Rad Biol Med 8: 583-599, 1990.

107 Abrahim NN, Kanthimathi MS and Abdul-Aziz A: Piper betle shows antioxidant activities, inhibits MCF-7 cell proliferation and increases activities of catalase and superoxide dismutase. BMC Complem Altern Med 12: 220, 2012.

108 Hileman EO, Liu J and Albitar M: Intrinsic oxidative stress in cancer cells: a biochemical basis for therapeutic selectivity. Cancer Chemother Pharmacol 53: 209-219, 2004.

109 Wang S, Meckling KA, Marcone MF, Kakuda Y and Tsao R: Can phytochemical antioxidant rich foods act as anti-cancer agents? Food Res Int 44: 2545-2554, 2011.

110 Bilgin A, Ertem B and Gök Y: Novel Porphyrazines Containing Peripherally Functionalized Macrocyclic $\left(\mathrm{N}_{2} \mathrm{O}_{2}, \mathrm{~N} 2 \mathrm{~S} 2\right)$ Units: Synthesis and characterization. Dyes and Pigments 80: 187-193, 2009.

111 Buytaert E, Dewaele M and Agostinis P: Molecular effectors of multiple cell death pathways initiated by photodynamic therapy. Biochim Biophys Acta 1776(1): 86-107, 2007.

112 Chen Z, Xu P, Chen J, Chen H, Hu P, Chen X, Lin L, Huang Y, Zheng K, Zhou S, Li R, Chen S, Liu J and Xue J: Zinc phthalocyanine conjugated with the amino-terminal fragment of urokinase for tumor targeting photodynamic therapy. Acta Biomaterialia 10(10): 4257-4268, 2012. 
113 Anand S, Ortel BJ, Pereira SP, Hasban T and Maytin EV: Biomodulatory approaches to photodynamic therapy for solid tumors, Mini review. Cancer Lett 326(1): 8-16, 2012.

114 Arumainayagam N, Moore CM, Ahmed HU and Emberton M: Photodynamic therapy for focal ablation of the prostate. World J Urol 28(5): 571-576, 2010

115 Baron ED, Malbasa CL, Santo-Domingo D, Fu P, Miller JD, Hanneman KK, Hsia AH, Oleinick NL, Colussi VC and Cooper KD: Silicon phthalocyaninen (Pc4) photodynamic therapy is a safe modality for cutaneous neoplasms: results of a phase I clinical trial. Lasers Surg Med 42(10): 728-735, 2010.

116 Camerin M, Magaraggia M, Soncin M, Jori G, Moreno M, Chambrier I, Cook MJ and Russell DA: The in vivo efficacy of phthalocyanine-nanoparticle conjugates for the photodynamic therapy of amelanotic melanoma. Eur J Cancer 46(10): 19101918, 2010.

117 Johansson A, Palte G, Schnell O, Tonn J-C and Herms J, Stepp $\mathrm{H}$ : 5-aminolevulinic acid-induced protoporphyrin IX levels in tissue of human malignant brain tumors. Photochem Photobiol 86(6): 1373-1378, 2010.

118 Sanovic R, Verwanger T, Hartl A and Krammer B: Low dose hypericin-PDT induces complete tumor regression in BALB/c mice bearing CT29 colon carcinoma. Photodiagnosis Photodyn Ther 8(4): 291-296, 2011

119 Kinsella TJ, Baron ED, Colussi VC, Cooper KD, Hoppel CL, Ingalls ST, Kenny ME, Li X, Oleinick NL, Stevens SR and Remick SC: Preliminary clinical and pharmacological investigation of photodynamic therapy with the silicon phthalocyanine photosensitizer Pc4 for primary or metastatic cutaneous cancers. Front Oncol 1: 14, 2011.

120 Capella MAM and Capella LS: A light in multidrug resistance: photodynamic treatment of multidrug-resistant tumors. J Biomed Sci 10(4): 361-366, 2003.

121 Liu FS: Mechanisms of chemotherapeutic drug resistance in cancer therapy - a quick review. Taiwan J Obset Gynecol 48(3): 239-244, 2009

122 Fletcher JI, Haber M, Henderson MJ and Norris MD: ABC transporters in cancer: more than just drug efflux pumps. Nat Rev Cancer 10: 147-156, 2010.

123 Fojo $\mathrm{T}$ and Coley HM: The role of efflux pumps in drugresistant metastatic breast cancer: new insights and treatment strategies. Clin Breast Cancer 7(10): 749-756, 2007.

124 Dean M, Rzhetsky A and Allikmets R: The human ATP-binding cassette $(\mathrm{ABC})$ transporter superfamily. Genome Res 11(7): 1156-1166, 2001.

125 Gottesman MM and Pastan IH: The role of multidrug resistance efflux pumps in cancer: Revisiting the JNCI publication exploring the expression of the MDR1 (p-glycoprotein) gene. J Nat Cancer Inst 107(9): djv222, 2015.

126 Ambudkar SV, Kimchi-Sarfaty C, Sauna ZE and Gottesman MM: P-glycoprotein: from genomics to mechanism. Oncogene 22(47): 7468-7485, 2003

127 Binkhathlan Z and Lavasanifar A: P-glycoprotein Inhibition as a Therapeutic Approach for Overcoming Multidrug Resistance in Cancer: Current Status and Future Perspectives. Curr Cancer Drug Targets 13(3): 326-346, 2013.

128 Cole SPC: Targeting Multidrug Resistance Protein 1 (MRP1, ABCC1): Past, Present, and Future. Annu Rev Pharmacol Toxicol 54: 95-117, 2014.
129 Gottesman MM and Ling V: The molecular basis of multidrug resistance in cancer: The early years of P-glycoprotein research. FEBS Lett 580: 998-1009, 2006.

130 Schaich M and Illmer T: Mdr1 gene expression and mutations in Ras proto-oncogenes in acute myeloid leukemia. Leuk Lymphoma 43(7): 1345-1345, 2002.

131 Aller SG, Yu J, Ward A, Weng Y, Chittaboina S, Zhuo R, Harrell PM, Trinh YT, Zhang Q, Urbatsch IL and Chang G: Structure of P-glycoprotein reveals a molecular basis for polyspecific drug binding. Science 323(5922): 1718-1722, 2009.

132 Ferreira RJ, Ferreira M-JU and dos Santos DJVA: Insights on P-Glycoprotein's efflux mechanism obtained by molecular dynamics simulations. J Chem Theory Comput 8(6): 18531864, 2012.

133 Detty MR, Gibson SL and Wagner SJ: Current clinical and preclinical photosensitizers for use in photodynamic therapy. J Med Chem 47(16): 3897-3915, 2004.

134 Dellinger M, Moreno G, Sallet C, Tapiero H and Lampidis TJ: Cytotoxic and photodynamic effects of photofrin on sensitive and multidrug-resistant Friend leukemia cells. Int. J Radiat Biol 62(6): 735-741, 1992.

135 Kessel D and Erickson C: Porphyrin photosensitization of multi-drug resistant cell types. Photochem Photobiol 55: $397-$ 399, 1992

136 Teiten M-H, Bezdetnaya L, Merlin J-L, Bour-Dill C, Pauly ME, Dicato $M$ and Guillemin $F$ : Effect of metatetra(hydroxyphenyl)clorin (mTHPC)-mediated photodynamic therapy on sensitive and multidrug resistant breast cancer cells. J Photochem Photobiol B Biol 62: 146-152, 2001.

137 Tang P M-K, Liu X-Z, Zhang D-M, Fong WP and Fung KP: Pheophorbide a photodynamic therapy induces apoptosis via mitochondrial-mediated pathway in human uterine carcinoma. Cancer Biol Ther 8(6): 533-539, 2009.

138 Frazier DL, Bamhill MA, Lu X, Jones E, Niemeyer G, Mishu L and Lothrop CD: Effect of multidrug-resistant P-glycoprotein gene expression on chloroaluminium tetrasulfonate phthalocyanine concentration. Lasers Surg Med 13: 511-516, 1993.

139 Nakanishi $\mathrm{T}$ and Ross DD: Breast cancer resistance protein (BCRP/ABCG2): Its role in multidrug resistance and regulation of its gene expression (Review). Chin J Cancer 31(2): 73-99, 2012.

140 Munoz M, Henderson M, Haber M and Norris M: Role of the MRP1/ABCC1 multidrug transporter protein in cancer (Critical review). IUBMB Life 59(12): 752-757, 2007.

141 Robey RW, Steadman K, Polgar O, Morisaki K, Blayney M, Mistry $\mathrm{P}$ and Bates SE: Pheophorbide a is a specific probe for ABCG2 function and inhibition. Cancer Res 64(4): 1242-1246, 2004.

142 Robey RW, Steadman K, Polgar O and Bates SE: ABCG2mediated transport of photosensitizers: Potential impact on photodynamic therapy, Cancer Biol Ther 4(2): 195-202, 2005.

143 Hagiya Y, Endo Y, Yonemura Y, Takahashi K, Ishizuka M, Abe F, Tanaka T, Okura I, Nakajima M, Ishikawa T and Ogura S: Pivotal roles of peptide transporter PEPT1 and ATP-binding cassette $(\mathrm{ABC})$ transporter $\mathrm{ABCG} 2$ in 5-aminolevulinic acid (ALA)-based photocytotoxicity of gastric cancer cells in vitro. Photodiag Photodyn Ther 9(3): 204-214, 2012.

144 Morgan J, Jackson JD, Zheng X, Pandey SK and Pandey RK: Substrate affinity of photosensitizers derived from chlorophylla: the ABCG2 transporter affects the phototoxic response of 
side population stem cell-like cancer cells to photodynamic therapy. Mol Pharm 7(5): 1789-804, 2010.

145 Liu W, Baer MR, Bowman MJ, Pera P, Zheng X, Morgan J, Pandey RA and Oseroff AR: The tyrosine kinase inhibitor imatinib mesylate enhances the efficacy of photodynamic therapy by inhibiting ABCG2. Clin Cancer Res 13(8): 24632470, 2007.

146 Usuda J, Tsunoda Y, Ichinose S, Ishizumi T, Ohtani K, Maehara S, Ono S, Tsutsui H, Ohira T, Okunaka T, Furukawa K, Sugimoto $\mathrm{Y}$, Kato $\mathrm{H}$ and Ikeda N: Breast cancer resistant protein (BCRP) is a molecular determinant of the outcome of photodynamic therapy (PDT) for centrally located early lung cancer. Lung Cancer 67(2): 198-204, 2010.

147 Iqbal N and Iqbal N: Imatinib: A Breakthrough of Targeted Therapy in Cancer. Chemother Res Prac 2014: 357027, 2014.

$148 \mathrm{He} \mathrm{M}$ and Wei M-J: Reversing multidrug resistance by tyrosine kinase inhibitors. Chin J Cancer 31(3): 126-133, 2012.

149 Sun W, Kajimoto Y, Inoue H, Miyatake S-I, Ishikawa T and Kuroiwa T: Gefitinib enhances the efficacy of photodynamic therapy using 5-aminolevulinic acid in malignant brain tumor cells. Photodiag Photodyn Ther 10(1): 42-50, 2013.

150 Bebes A, Nagy T, Bata-Csörgő Z, Kemény L, Dobozy A and Széll M: Specific inhibition of the ABCG2 transporter could improve the efficacy of photodynamic therapy. J Photochem Photobiol B: Biol 105(2): 162-166, 2011.

151 Jendželovský R, Mikeš J, Koval' J, Souček K, Procházková J, Kello M, Sackova V, Hofmanova J, Kozubik A and Fedorocko P: Drug efflux transporters, MRP1 and BCRP, affect the outcome of hypericin-mediated photodynamic therapy in HT29 adenocarcinoma cells. Photochem Photobiol Sci 8: 17161723, 2009.

151 Amin L: P-glycoprotein Inhibition for Optimal Drug Delivery. Drug Target Insights 7: 27-34, 2013.

152 Kim RB: Drugs and P-glycoprotein substrates, inhibitors and inducers. Drug Metab Rev 34(1-2): 47-54, 2002.

153 Srivalli KMR and Lakshmi PK: Overview of P-glycoprotein inhibitors: a rational outlook. Braz J Pharm Sci 48(3): 353-367, 2012.

154 Kerkelä R, Grazette L, Yacobi R, Iliescu C, Patten R, Beahm C, Walters B, Shevtsov S, Pesant S, Clubb FJ, Rosenzweig A, Salomon RN, Van Etten RA, Alroy J, Durand JB and Force T: Cardiotoxicity of the cancer therapeutic agent imatinib mesylate. Nat Med 12: 908-916, 2006.

155 Porta C, PaglinoI C and Bonomi IL: Uncovering Pandora's vase: the growing problem of new toxicities from novel anticancer agents. The case of sorafenib and sunitinib. Clin Exp Med 7(4): 127-134, 2007.

156 Schmidinger M, Zielinski CC, Vogl UM, Bojic A, Bojic M, Schukro C, Ruhsam M, Hejna M and Schmidinger H: Cardiac Toxicity of Sunitinib and Sorafenib in Patients With Metastatic Renal Cell Carcinoma. J Clin Oncol 26(32): 5204-5212, 2008.

157 Avci P, Erdem SS and Hamblin MR: Photodynamic Therapy: One Step Ahead with Self-Assembled Nanoparticles. J Biomed Nanotechnol 10(9): 1937-1952, 2014.

158 Lee YE and Kopelman R: Polymeric nanoparticles for photodynamic therapy. Methods Mol Biol 726: 151-178, 2011.

$159 \mathrm{Li} \mathrm{L}$ and Huh KM: Polymeric nanocarrier systems for photodynamic therapy. Biomaterials Res 18: 19, 2014.

160 Yin Q, Shen J, Zhang Z, Yu H and Li Y: Reversal of multidrug resistance by stimuli-responsive drug delivery systems for therapy of tumor. Adv Drug Deliv Rev 65(13-14): 1699-1715, 2013.

161 Aziz F, Telara S, Moseley H, Goodman C, Manthri P and Eljamel MS: Photodynamic therapy adjuvant to surgery in metastatic carcinoma in brain. Photodiagn Photodyn Ther 6: 227-230, 2009.

162 Yano S, Hirohara S, Obata M, Hagiya Y, Ogura S-O, Ikeda A, Kataoka H, Tanaka $M$ and Joh T: Current states and future views in photodynamic therapy. J Photochem Photobiol C: Photochem Rev 12: 46-67, 2011.

163 Mojzisova H, Bonneau S, Vever-Bizet C and Brault D: Cellular uptake and subcellular distribution of chlorin e6 as functions of $\mathrm{pH}$ and interactions with membranes and lipoproteins. Biochim Biophys Acta 1768: 2748-2756, 2007.

164 Sabrian-Vazquez M, Jensen TJ and Vicente MG: Synthesis and cellular studies of PEG-funtionalized meso-tetraphenylporphyrins. J Photochem Photobiol B: Biol 86(1): 9-21, 2007.

165 Sharma SK, Krayer M, Sperandio FF, Huang L, Huang YY, Holten D, Lindsey JS and Hamblin MR: Synthesis and evaluation of cationic bacteriochlorin amphiphiles with effective in vitro photodynamic activity against cancer cells at low nanomolar concentration. J Porphyr Phthalocyanines 17(1-2): 73-85, 2013.

166 Wawrzyńska M, Kałas W, Biały D, Zioło E, Arkowski J, Mazurek $\mathrm{W}$ and Strzadała L: In vitro photodynamic therapy with Chlorin e6 leads to apoptosis of human vascular smooth muscle cells. Arch Immunol Ther Exp 58: 67-75, 2010.

167 Keskin B, Köseoğlu Y, Avciata U and Gül A: Synthesis and EPR studies of porphyrazines with bulky substituents. Polyhedron 27: 1155-1160, 2008.

168 Lee S, Vesper BJ, Zong H, Hammer ND, Elseth KM, Barrett AG, Hoffman BM and Radosevich JA: Synthesis and biological analysis of thiotetra(ethylene glycol) monomethyl etherfunctionalized porphyrazines: Cellular uptake and toxicity studies. Metal Based Drugs 2008: 391418, 2008.

169 Santin G, Bottone MG, Malatesta M, Scovassi AI, Bottiroli G, Pellicciari $\mathrm{C}$ and Croce AC: Regulated forms of cell death are induced by the photodynamic action of the fluorogenic substrate, hypocrellin B-acetate. J Photochem Photobiol B: Biol 125: 90-97, 2013.

170 Thomas AP, Saneesh Babu PS, Asha Nair S, Ramakrishnan S, Ramaiah D, Chandrashekar TK, Srinivasan A and Radhakrishna Pillai M: Meso-Tetrakis(p-sulfonatophenyl)N-Confused porphyrin tetrasodium salt: A potential sensitizer for photodynamic therapy. J Med Chem 55: 5110-5120, 2012.

171 Zhao Z, Chan P-S, Li H, Wong KL, Wong RN, Mak NK, Zhang J, Tam HL, Wong WY, Kwong DW and Wong WK: Highly selective mitochondria-targeting amphiphilic silicon(IV) phthalocyanines with axially ligated rhodamine $\mathrm{B}$ for photodynamic therapy. Inorg Chem 51: 812-821, 2012.

172 Ibbotson SH: An overview of topical photodynamic therapy in dermatology. Photodiag Photodyn Ther 7: 16-23, 2010.

173 Rijcken CJF, Hofman J-W, van Zeeland F, Hennink WE and van Nostrum CF: Photosensitizer-loaded biodegradable polymeric micelles: Preparation, characterization and in vitro PDT efficacy. J Control Release 124: 144-153, 2007.

174 Goslinski T, Osmalek T and Mielcarek J: Photochemical and spectral characterization of peripherally modified porphyrazines. Polyhedron 28: 3839-3843, 2009.

175 Wyld L, Reed MW and Brown NJ: Differential cell death response to photodynamic therapy is dependant on dose and cell type. Br J Cancer 84(10): 1384-1386, 2001. 
176 Miki Y, Swensen J, Shattuck-Eidens D, Futreal PA, Harshman K, Tavtigian S, Liu Q, Cochran C, Bennett ML, Ding W, Bell R, Rosenthal J, Hussey C, Tran T, McClure M, Frye C, Hattier T, Phelps R, Haugen-Strano A, Katcher H, Yakumo K, Gholami Z, Shaffer D, Stone S, Bayer S, Wray C, Bogden R, Dayananth P, Ward J, Tonin P, Narod S, Bristow PK, Norris FH, Helvering L, Morrison P, Rosteck P, Lai M, Barrett CJ, Lewis C, Neuhausen S, Cannon-Albright L, Goldgar D, Wiseman R, Kamb A and Skolnick MH: A strong candidate for the breast and ovarian cancer susceptibility gene BRCA1. Science 266: 66-71, 1994.

177 Vidarsdottir L, Bodvarsdottir SK, Hilmarsdottir H, Tryggvadottir L and Eyfjord JE: Breast cancer risk associated with AURKA 91T to A polymorphism in relation to BRCA mutations. Cancer Lett 250: 206-212, 2007.

178 Yang XH, Sladek TL, Liu X, Butler BR, Froelich CJ and Thor AD: Reconstitution of caspase 3 sensitizes MCF-7 breast cancer cells to doxorubicin- and etoposide-induced apoptosis. Cancer Res 61: 348-354, 2001.

179 Soengas MS, Capodieci P, Polsky D, Mora J, Esteller M, OpitzAraya X, McCombie R, Herman JG, Gerald WL, Lazebnik YA, Cordón-Cardó C and Lowe SW: Inactivation of the apoptosis effector Apaf-1 in malignant melanoma. Nature 409: 207-211, 2001.

180 Hodis E, Watson IR, Kryukov GV, Arold ST, Imielinski M, Theurillat JP, Nickerson E, Auclair D, Li L, Place C, Dicara D, Ramos AH, Lawrence MS, Cibulskis K, Sivachenko A, Voet D, Saksena G, Stransky N, Onofrio RC, Winckler W, Ardlie K, Wagle N, Wargo J, Chong K, Morton DL, Stemke-Hale K, Chen G, Noble M, Meyerson M, Ladbury JE, Davies MA, Gershenwald JE, Wagner SN, Hoon DS, Schadendorf D, Lander ES, Gabriel SB, Getz G, Garraway LA and Chin L: A landscape of driver mutations in melanoma. Cell 150(2): 251263, 2012.

181 Bullani RR, Wehrli P, Viard-Leveugle I, Rimoldi D, Cerottini JC, Saurat JH, Tschopp J and French LE: Frequent downregulation of Fas(CD95) expression and function in melanoma. Melanoma Res 12(3): 263-270, 2002.

182 Xu C, Hou Z, Zhan P, Zhao W, Chang C, Zou J, Hu H, Zhang Y, Yao X, Yu L and Yan J: EZH2 regulates cancer cell migration through repressing TIMP-3 in non-small cell lung cancer. Med Oncol 30(4): 713, 2013.

183 Xaio F, Bai Y, Chen Z, Li Y, Luo L, Huang J, Yang J, Liao H and Guo L: Downregulation of HOXA1 gene affects small cell lung cancer cell survival and chemoresistance under the regulation of miR-100. Eur J Cancer 50(80): 1541-1554, 2014.

$184 \mathrm{Wu}$ C-Y, Tseng R-C, Hsu H-S, Wang YC and Hsu MT: Frequent down-regulation of hRAB37 in metastatic tumor by genetic and epigenetic mechanisms in lung cancer. Lung Cancer 63: 360-367, 2009.

$185 \mathrm{Li} \mathrm{W}$, Yu XY, Yang Y, Zhang CP, Guo LP and Lu SH: Expression of esophageal cancer related gene 4 (ECRG4), a novel tumor suppressor gene, in esophageal cancer and its inhibitory effect on the tumor growth in vitro and in vivo. Int $\mathrm{J}$ Cancer 125(7): 1505-1513, 2009.

186 He Y, Wang Y, Li P, Zhu S, Wang J and Zhang S: Identification of GPX3 epigenetically silenced by $\mathrm{CpG}$ methylation in human esophageal squamous cell carcinoma. Dig Dis Sci 56(3): 681688, 2011.

187 Zhu YH, Fu L, Chen L, Qin YR, Liu H, Xie F, Zeng T, Dong SS, Li J, Li Y, Dai Y, Xie D and Guan XY: Downregulation of the novel tumor suppressor DIRAS1 predicts poor prognoses in esophageal squamous cell carcinoma. Cancer Res 73: 2298, 2013.

188 Osborne CK, Shou J, Massarweh S and Schiff R: Crosstalk between estrogen receptor and growth factor receptor pathways as a cause for endocrine therapy resistance in breast cancer. Clin Cancer Res 11(Suppl): 865s-870s, 2005.

189 Verhaegen M, Checinska A, Riblett MB, Wang S and Soengas MS: E2F1-dependendt oncogenic addiction of melanoma cells to MDM2. Oncogene 31: 828-841, 2012.

190 Huang FW, Hodis E, Xu MJ, Kryukov GV, Chin L and Garraway LA: Highly recurrent TERT promoter mutations in human melanoma. Science 339(6122): 957-959, 2013.

191 Suda K, Tomizawa K and Mitsudomi T: Biological and clinical significance of KRAS mutations in lung cancer: an oncogenic driver that contrasts with EGFR mutation. Cancer Metastasis Rev 29(1): 49-60, 2010.

192 Hammerman PS, Sos ML, Ramos AH, Xu C, Dutt A, Zhou W, Brace LE, Woods BA, Lin W, Zhang J, Deng X, Lim SM, Heynck S, Peifer M, Simard JR, Lawrence MS, Onofrio RC, Salvesen HB, Seidel D, Zander T, Heuckmann JM, Soltermann A, Moch H, Koker M, Leenders F, Gabler F, Querings S, Ansén S, Brambilla E, Brambilla C, Lorimier P, Brustugun OT, Helland A, Petersen I, Clement JH, Groen H, Timens W, Sietsma H, Stoelben E, Wolf J, Beer DG, Tsao MS, Hanna M, Hatton C, Eck MJ, Janne PA, Johnson BE, Winckler W, Greulich H, Bass AJ, Cho J, Rauh D, Gray NS, Wong KK, Haura EB, Thomas RK and Meyerson M: Mutations in the DDR2 kinase gene identify a novel therapeutic target in squamous cell lung cancer. Cancer Discov 1(1): 78-89, 2011.

193 Lin D-C, Hao J-J, Nagata Y, Xu L, Shang L, Meng X, Sato Y, Okuno Y, Varela AM, Ding LW, Garg M, Liu LZ, Yang H, Yin D, Shi ZZ, Jiang YY, Gu WY, Gong T, Zhang Y, Xu X, Kalid O, Shacham S, Ogawa S, Wang MR and Koeffler HP: Genomic and molecular characterization of esophageal squamous cell carcinoma. Nat Genet 46: 467-473, 2014.

194 Lind MJ: Principles of cytotoxic chemotherapy. Medicine 36(1): 19-23, 2008

195 Malhotra V and Perry MC: Classical chemotherapy: mechanisms, toxicities and the therapeutic window. Cancer Biol Ther 2(4 Suppl 1): S2-4, 2003.

196 Parker WB: Enzymology of purine and pyrimidine antimetabolites used in the treatment of cancer. Chem Rev 109(7): 2880-2893, 2009.

197 Morris PG and Fornier MN: Microtubule active agents: beyond the taxane frontier. Clin Cancer Res 14(22): 7167-72, 2008.

198 Yue QX, Liu X and Guo DA: Microtubule-binding natural products for cancer therapy. Planta Med 76(11): 1037-1043, 2010.

199 Nitiss JL: Targeting DNA topoisomerase II in cancer chemotherapy. Nat Rev Cancer 9(5): 338-50, 2009.

200 Bolenz C, Cao Y, Arancibia MF, Trojan L, Alken P and Michel MS: Intravesical mitomycin $C$ for superficial transitional cell carcinoma. Expert Rev Anticancer Ther 6(8): 1273-1282, 2006.

201 Tacar O and Dass CR: Doxorubicin-induced death in tumour cells and cardiomyocytes: is autophagy the key to improving future clinical outcomes? J Pharm Pharmacol 65(11): 15771589, 2013.

202 Turan T, Karacay O, Tulunay G, Boran N, Koc S, Bozok S and Kose MF: Results with EMA/CO (etoposide, methotrexate, 
actinomycin D, cyclophosphamide, vincristine) chemotherapy in gestational trophoblastic neoplasia. Int J Gynecol Cancer 16(3): 1432-1438, 2006.

203 Lumachi F, Luisetto G, Basso SM, Basso S, Brunello A and Camozzi V: Endocrine therapy of breast cancer. Curr Med Chem 18(4): 513-522, 2011.

204 Stuart-Harris R and Davis A: Optimal adjuvant endocrine therapy for early breast cancer. Womens Health (Lond) 6(3): 383-398, 2010

205 Khalkhali-Ellis Z, Christian AL, Kirschmann DA, Edwards EM, Rezaie-Thompson M, Vasef MA, Gruman LM, Seftor RE, Norwood LE and Hendrix MJ: Regulating the tumor suppressor gene maspin in breast cancer cells: a potential mechanism for the anticancer properties of tamoxifen. Clin Cancer Res 10(2): 449-454, 2004.

206 Gravekamp C: Cancer vaccines in old age. Exp Gerontol 42(5): 441-450, 2007.

207 Oudard S: Progress in emerging therapies for advanced prostate cancer. Cancer Treat Rev 39(3): 275-289, 2013.

208 Dranoff G: Cytokines in cancer pathogenesis and cancer therapy. Nat Rev Cancer 4(1): 11-22, 2004.

209 Lasfar A, Abushahba W, Balan M and Cohen-Solal KA: Interferon Lambda: a new sword in cancer immunotherapy. Clin Dev Immunol 2011: 349575, 2011.

210 Gelderman KA, Tomlinson S, Ross GD and Gorter A: Complement function in $\mathrm{mAb}$-mediated cancer immunotherapy. Trends Immunol 25(3): 158-164, 2004.

211 Scott AM, Wolchock JD and Old LJ: Antibody therapy in cancer. Nat Rev Cancer 12(4): 278-287, 2012.

212 Seidel UJ, Schlegel P and Lang P: Natural killer cell mediated antibody-dependent cellular cytotoxicity in tumor immunotherapy with therapeutic antibodies. Front Immunol 4: 76, 2013.

213 Sharkey RM and Goldenberg DM: Cancer radioimmunotherapy. Immunotherapy 3(3): 349-370, 2011.

214 Zhang JF, Hu C, Geng Y, Selm J, Klein SB, Orazi A and Taylor MW: Treatment of a human bast cancer xenograft with an adenovirus vector containing an interferon gene results in rapid regression due to viral oncolysis and gene therapy. PNAS 93: 4513-4518, 1996.

215 Beale SI: Biosynthesis of the tetrapyrrole pigment precursor, delta-aminolevulinic acid, from glutamate. Plant Physiol 93(4): 1273-1279, 1990.

216 Gravier J, Schnieder R, Frochot C, Bastogne T, Schmitt F, Didelon J, Guillemin F and Barberi-Heyob M: Improvement of meta-tetra(hydroxyphenyl)chlorine-like photosensitizer selectivity with folate-based targeted delivery. Synthesis and in vivo delivery studies. J Med Chem 51(13): 3867-3877, 2008.

217 Castano AP, Demidova TN and Hamblin MR: Mechanisms in photodynamic therapy: Part three -Photosensitizer pharmacokinetics, biodistribution, tumor localization and modes of tumor destruction. Photodiag Photodyn Ther 2: 91-106, 2005.

218 Robertson CA, Hawkins Evans D and Abrahamse H: Photodynamic therapy (PDT): A short review on cellular mechanisms and cancer research applications for PDT. J Photochem Photobiol B: Biol 96: 1-8, 2009.

219 Soriano J, Garcia-Diaz M, Mora M, Sagristá ML, Nonell S, Villanueva A, Stockert JC and Cañete M: Liposomal temocene (m-THPPo) photodynamic treatment induces cell death by mitochondria-independent apoptosis. Biochim Biophys Acta 1830: 4611-4620, 2013.
220 Tang PMK, Zhang DM, Xuan NHB, Tsui SK, Waye MM, Kong SK, Fong WP and Fung KP: Photodynamic therapy inhibits pglycoprotein mediated multidrug resistance via JNK activation in human hepatocellular carcinoma using the photosensitizer pheophorbide a. Mol Cancer 8: 56, 2009.

221 Allison RR, Downie GH, Cuenca R, Hu XH, Childs CJ and Sibata $\mathrm{CH}$ : Photosensitizers in clinical PDT. Photodiag Photodyn Ther 1: 27-42, 2004.

222 Sakamoto K, Ohno-Okumura E, Kato T, Watanabe M and Cook MJ: Investigation of zinc bis(1,4-didecylbenzo)-bis(2,3-pyrido) porphyrazine as an efficient photosensitizer by cyclic voltammetry. Dyes and Pigments 78(3): 213, 2008.

223 Sessler JL and Seidel D: Synthetic expanded porphyrin chemistry. Angewandte Chemie Int Ed 42: 5134-5175, 2003.

224 Goslinski T, Osmalek T and Mielcarek J: Photochemical and spectral characterization of peripherally modified porphyrazines. Polyhedron 28: 3839-3843, 2009.

225 Nemykin VN and Hadt RG: Interpretation of the UV-vis spectra of the meso(Ferrocenyl)-containing porphyrins using a TDDFT approach: Is Gouterman's classic four-orbital model still in play? J Phys Chem 114(45): 12062-12066, 2010.

226 Lafont D, Zorlu Y, Savoie H, Albrieux F, Ahsen V, Boyle RW and Dumoulin F: Monoglycoconjugated phthalocyanines: effect of sugar and linkage on photodynamic therapy. Photodiag Photodyn Ther 10(3): 252-259, 2013.

227 Senge MO: mTHPC - A drug on its way from second to third generation photosensitizer? Photodiag Photodyn Ther 9(2): 1709, 2012.

228 Zheng X, Morgan J, Pandey SK, Chen Y, Tracy E, Baumann H, Missert JR, Batt C, Jackson J, Bellnier DA, Henderson BW and Pandey RK: Conjugation of 2-(1'-Hexyloxyethyl)-2devinylpyropheophorbide-a (HPPH) to carbohydrates changes its subcellular distribution and enhances photodynamic activity in vivo. J Med Chem 52: 4306-4318, 2009.

229 Gyenge EB, Lüscher D, Forny P, Antoniol M, Geisberger G, Walt H, Patzke G and Maake C: Photodynamic mechanisms induced by a combination of hypericin and a chlorin basedphotosensitizer in head and neck squamous cell carcinoma cells. Photochem Photobiol 89: 150-162, 2013.

230 Villanueva A, Stockert JC, Cañete M and Acedo P: A new protocol in photodynamic therapy: enhanced tumour cell death by combining two different photosensitizers. Photochem Photobiol Sci 9: 295-297, 2010.

231 Yoo JO and Ha K: New insights into the mechanisms for photodynamic therapy-induced cancer cell death. Int Rev Cell Mol Biol 295: 139-174, 2012.

232 Bisland S: Light-delivery and imaging technologies advance PDT knowledge. Biophotonics Int 12(4): 44-49, 2005.

233 Amaravadi RK and Thompson CB: The roles of therapyinduced autophagy and necrosis in cancer treatment. Clin Cancer Res 13: 7271-9, 2007.

234 Kessel D and Oleinick NL: Initiation of autophagy by photodynamic therapy. Methods Enzymol 453: 1-16, 2009.

235 Nikoletopoulou V, Markaki M, Palikaras K and Tavernarakis N: Crosstalk between apoptosis, necrosis and autophagy. BBA Mol Cell Res 1833(12): 3448-3459, 2013.

236 Mroz P, Yaroslavsky A, Kharkwal GB and Hamblin MR: Cell death pathways in photodynamic therapy of cancer. Cancers 3: 2516-2539, 2011. 
237 Chwiłkowska A, Saczko J, Modrzycka T, Marcinkowska A, Malarska A, Bielewicz J, Patalas D and Banaś T: Uptake of photofrin II, a photosensitizer used in photodynamic therapy, by tumour cells in vitro. Acta Biochim Pol 50(2): 509-513, 2003.

238 Dolmans DE, Fukumura D and Jain RK: Photodynamic therapy for cancer. Nat Rev Cancer 3(5): 380-7, 2003.

239 Lang K, Mosinger J and Wagnerova DM: Photophysical properties of porphyrinoid sensitizers noncovalently bound to host molecule; models for photodynamic therapy. Coord Chem Rev 248: 321-350, 2004.

240 Zhang JX, Hansen CB, Allen TM, Boey A and Boch R: Lipidderivatized poly(ethylene glycol) micellar formulations of benzoporphyrin derivatives. J Controlled Rel 86: 323-338, 2003.

241 Leng F, Wang X, Jin L and Yin B: The synthesis and properties of unsymmetrical porphyrazines annulated with a tetrathiafulvalene bearing two tetraethylene glycol units. Dyes and Pigments 87: 89-94, 2010.

242 Mbatha BG: Synthesis and Characterization of Porphyrazines with Chiral Recognition Motifs. RSC Advances 14, 2006. doi: 10.1039/C5RA20871H [Epub ahead of print]

243 Bergendahl LT and Paterson MJ: Excited states of porphyrin and porphycene aggregates: Computational insights. Comput Theor Chem 1040-1041: 274-286, 2014.

244 Ribeiro AO, Tomé JPC, Neves MGPM, Tomé AC, Cavaleiro J, Iamamoto $\mathrm{Y}$ and Torres $\mathrm{T}$ : [1,2,3,4-tetrakis $(\alpha / \beta$ - $\mathrm{D}$-galactopyranose-6-yl)-phthalocyaninato]zinc(II): A Water-Soluble Phthalocyanine. Tetrahedron Lett 47(52): 9177-9180, 2006.

245 Ritz R, Wein HT, Dietz K, Schenk M, Roser F, Tatagiba M and Strauss WS: Photodynamic therapy of malignant glioma with hypericin: Comprehensive in vitro study in human glioblastoma cell lines. Int J Oncol 30: 659-667, 2007.

246 Höpfner M, Maaser K, Theiss A, Lenz, Sutter AP, Kashtan H, von Lampe B, Riecken EO, Zeitz M and Scherübl H: Hypericin activated by an incoherent light source has photodynamic effects on esophageal cancer M cells. Int J Colorectal Dis 18: 239-247, 2003.

247 Delaey EM, Obermuëller R, Zupkó I, De Vos D, Falk H and de Witte PA: In vitro study of the phototoxicity of some hypericin analogs on different cell lines. Photochem Photobiol 74(2): 164-171, 2001

248 Zeisser-Labouèbe $\mathrm{M}$, Lange $\mathrm{N}$, Gurny $\mathrm{R}$ and Delie F: Hypericin-loaded nanoparticles for the photodynamic treatment of ovarian cancer. Int J Pharm 326: 174-181, 2006.

249 Laffers W, Busse A-C, Mahrt J, Hguyen P, Gerstner AO, Bootz $\mathrm{F}$ and Wessels JT: Photosensitizing effects of hypericin on head neck squamous cell carcinoma in vitro. Eur Arch Otorhinolaryngol 272: 711-718, 2015.

250 Ali SM, Chee SK, Yuen GY and Olivo M: hypericin induced death receptor mediated apoptosis in photoactivated tumor cells. Int J Mol Med 9: 601-616, 2002.

251 Buytaert E, Matroule JY, Durinck S, Close P, Kocanova S, Vandenheede JR, de Witte PA, Piette J and Agostinis P: Molecular effectors and modulators of hypericin-mediated cell death in bladder cancer cells. Oncogene 27: 1916-1929, 2008.

252 Solár P, Chytilová M, Solárová Z, Mojžiš J, Ferenc P and Fedoročko P: Photodynamic therapy with hypericin improved by targeting HSP90 associated proteins. Pharmaceuticals 4: 1488-1502, 2011.
255 Sharma KV and Davids LM: Hypericin-PDT-induced rapid necrotic death in human squamous cell carcinoma cultures after multiple treatment. Cell Biol Int 36(12): 1261-1266, 2012.

256 Sharma KV, Bowers N and Davids LM: Phototherapy-induced killing is enhanced in depigmented metastatic melanoma cells. Cell Biol Int 35(9): 939-944, 2013.

257 Kleemann B, Loos B, Scriba TJ, Lang D and Davids LM: St John's wort (hypericum perforatum L.) photomedicine: hypericin-photodynamic therapy induces metastatic melanoma cell death. PLoS ONE 9(7): e103762, 2014.

258 Chen X, Zhao P, Chen F, Li L and Luo R: Effect and mechanism of 5-aminolevulinic acid-mediated photodynamic therapy in esophageal cancer. Lasers Med Sci 26: 69-78, 2011.

259 Zawaka-Pankau J, Issaeva N, Hossain S, Pramanik A, Selivanova G and Podhajska AJ: Protoporphyrin IX interacts with wild type $\mathrm{p} 53$ protein in vitro and induces cell death of human colon cancer cells in a p53-dependent and -independent manner. J Biol Chem 282(4): 2466-2472, 2007.

260 Yow CMN, Wong CK, Huang Z and Ho RJ: Study of the efficacy and mechanism of ALA-mediated photodynamic therapy on human hepatocellular carcinoma cell. Liver International 27(2): 201-208, 2007.

261 Grebeňová D, Kuzelova K, Smetana K, Pluskalová M, Cajthamlová H, Marinov I, Fuchs O, Soucek J, Jarolím P and Hrkal Z: Mitochondrial and endoplasmic reticulum stressinduced apoptotic pathways are activated by 5 -aminolevulinic acid-based photodynamic therapy in HL60 leukemia cells. J Photochem Photobiol B: Biol 69(2): 71-85, 2003.

262 Wild PJ, Krieg RC, Seidle J, Stoehr R, Reher K, Hofmann C, Louhelainen J, Rosenthal A, Hartmann A, Pilarsky C, Bosserhoff AK and Knuechel R: RNA expression profiling of normal and tumor cells following photodynamic therapy with 5 -aminolevulinic acid-induced protoporphyrin IX in vitro. Mol Cancer Ther 4(4): 516-528, 2005.

263 Kammerer R, Buchner A, Palluch P, Pongratz T, Oboukhovskij K, Beyer W, Johansson A, Stepp H, Baumgartner R and Zimmermann W: Induction of immune mediators in glioma and prostate cancer cells by non-lethal photodynamic therapy. PLoS ONE 6(6): e21834, 2011.

264 Tsai T, Ji HT, Chiang P-C, Chou R-H, Chang WS and Chen CT: ALA-PDT results in phenotypic changes and decreased cellular invasion in surviving cancer cells. Lasers Surg Med 41: 305$315,2009$.

265 Sekkat N, van den Bergh H, Nyokong T and Lange N: Like a bolt from the blue: phthalocyanines in biomedical optics. Molecules 17: 98-144, 2012.

266 Plaetzer K, Kiesslich T, Krammer B and Hammerl P: Characterization of the cell death modes and the associated changes in cellular energy supply in response to AlPcS4-PDT. Photochem Photobiol Laser Appl 18: 7-19, 2002.

267 Kresfelder TL, Cronjé MJ and Abrahamse H: The effects of two metallophthalocyanines on the viability and proliferation of an esophageal cancer cell line. Photomed Laser Surg 27(4): 625631, 2009.

268 Horne TK, Abrahamse $\mathrm{H}$ and Cronjé MJ: Investigating the efficiency of novel metallo-phthalocyanine PDT-induced cell death in MCF-7 breast cancer cells. Photodiag Photodyn Ther 9: 215-224, 2012.

269 de Castro Pazos M, Pacheco-Soares C, Soares da Silva N, DaMatta RA and Pacheco MT: Ultrastructural effects of two 
phthalocyanines in CHO-K1 and HeLa cells after laser irradiation. Biocell 27(3): 301-309, 2003.

270 Xue LY, Chiu SM and Olienick NL: Photochemical destruction of the Bcl-2 oncoprotein during photodynamic therapy with the phthalocyanine photosensitizer Pc 4. Oncogene 20(26): 34203427, 2001.

271 Usuda J, Chiu S-M, Azizuddin K, Xue LY, Lam M, Nieminen AL and Oleinick NL: Promotion of photodynamic therapyinduced apoptosis by the mitochondrial protein Smac/DIABLO: Dependence on bax. Photochem Photobiol 76(2): 217-223, 2002.

272 Zhong B, Yin J-J, Bilski PJ, Chignell CF, Roberts JE and He YY: Enhanced photodynamic efficacy towards melanoma cells by encapsulation of Pc4 in silica nanoparticles. Toxicol Appl Pharmacol 241: 163-172, 2009.

273 Master AM, Rodriguez ME, Kenny ME, Oleinick NL and Gupta AS: Delivery of the photosensitizer Pc4 in PEG-PCL micelles for in vitro PDT studies. J Pharm Sci 99(5): 23862398, 2010.

274 El-Hussein A, Harith M and Abrahamse H: Assessment of DNA damage after photodynamic therapy using a metallophthalocyanine photosensitizer. Int J Photoenergy 2012: 281068, 2012.

275 Manoto SL and Abrahamse H: Effect of a newly synthesized Zn sulfophthalocyanine derivative on cell morphology, viability, proliferation and cytotoxicity in a human lung cancer cell line (A549). Lasers Med Sci 26: 523-530, 2011.

276 da Volta Soares M, Oliveira MR, dos Santos EP, da Brito Gitirana L, Barbosa GM, Quaresma CH and Ricci-Júnior E: Nanostructured delivery system for zinc phthalocyanine: preparation, characterization and phototoxicity study against human lung adenocarcinoma A549 cells. Int J Nanomedicine 6: 227-238, 2011.

277 Vittar NB, Awruch J, Azizuddin K and Rivarola V: Caspaseindependent apoptosis, in human MCF-7c3 breast cancer cells, following photodynamic therapy, with a novel water-soluble phthalocyanine. Int J Biochem Cell Biol 42(7): 1123-1131, 2010 .

278 Marino J, Garcia Vior MC, Dicelio LE, Roguin LP and Awruch $\mathrm{J}$ : Photodynamic effects of isosteric water-soluble phthalocyanines on human nasopharynx KB carcinoma cells. Eur J Med Chem 45: 4129-4139, 2010.

279 Haywood-Small SL, Vernon DI, Griffiths J, Schofield J and Brown SB: Phthalocyanine-mediated photodynamic therapy induces cell death and $\mathrm{G}_{0} / \mathrm{G}_{1}$ cell cycle arrest in cervical cancer cells. Biochem Biophys Res Commun 339: 569-576, 2006.

280 Rello-Varona S, Stockert JC, Cañete M, Acedo P and Villanueva A: Mitotic catastrophe induced in HeLa cells by photodynamic treatment with $\mathrm{Zn}(\mathrm{II})$-phthalocyanine. Int J Oncol 32: 1189-1196, 2008.
281 Lo P-C, Zhao B, Duan W, Fong W-P, Ko W-H and Ng DKP: Synthesis and in vitro photodynamic activity of monosubstituted amphiphilic zinc(II) phthalocyanines. Bioorg Med Chem Lett 17: 1073-1077, 2007.

282 Bui-Xuan N-H, Tang P M-K and Wong CK: Photo-activated pheophorbide-a, an active component of Scutellaria barbata, enhances apoptosis via the suppression of ERK-mediated autophagy in the estrogen-receptor negative human breast adenocarcinoma cells MBA-MD-231. J Ethnopharmacol 131(1): 95-103, 2010.

283 Liu L, Leung AWN, Xia XS, Bai DQ, Lin HD and Xu CS: Apoptosis of pancreatic adenocarcinoma cells induced by LEDactivated pheophorbide a. Laser Phys Lett 8(2): 150-154, 2011.

284 Tian Y, Leung W, Yue K and Mak N: Cell death induced by MPPa-PDT in prostate carcinoma in vitro and in vivo. Biochem Biophys Res Comm 348(2): 413-420, 2006.

285 Chen Y-C and Li W-T: Pheophorbide a mediated photodynamic therapy against human epidermoid carcinoma cells (A431). Proc SPIE Int Soc Opt Eng 7886, 2011. doi: 10.1117/12.874978 [E-pub ahead of print]

286 Huang Z: A review of progress in clinical photodynamic therapy. Technol Cancer Res Treat 4(3): 283-293, 2005.

287 Ma L, Moan J and Berg K: Evaluation of a new photosensitizer meso-tetra-hydroxyphenyl-chlorin, for use in photodynamic therapy: a comparison of it photobiological properties with those of two other photosensitizers. Int J Cancer 57: 883-888, 1994.

288 Bovis MJ, Woodhams JH, Loizidou M, Scheglmann D, Bown $\mathrm{SG}$ and Macrobert AJ: Improved in vivo delivery of m-THPC via pegylated liposomes for use in photodynamic therapy. J Control Release 157: 196-205, 2012.

289 Rosenthal DI, Nurenberg P, Becerra CR, Frenkel EP, Carbone DP, Lum BL, Miller R, Engel J, Young S, Miles D and Renschler MF: A phase I single-dose trial of gadolinium texaphyrin (Gd-Tex), a tumor selective radiation sensitizer detectable by magnetic resonance imaging. Clin Cancer Res 5: 739-745, 1999.
Received April 21, 2017

Revised May 7, 2017

Accepted May 8, 2017 